LBNL 43371

\title{
Sensitivity of Forced Air Distribution System Efficiency to Climate, Duct Location, Air Leakage and Insulation
}

\author{
Iain S. Walker \\ Energy Performance of Buildings Group \\ Environmental Energy Technologies Division \\ Lawrence Berkeley National Laboratory \\ Berkeley. CA. 94720
}

This work was supported by the Assistant Secretary for Energy Efficiency and Renewable Energy, Office of Building Technologies, of the U.S. Department of Energy under Contract No. DE-AC03-76SF00098.

This work was supported by the U.S. Environmental Protection Agency under Contract No. DW89938061-01 
Table of Contents

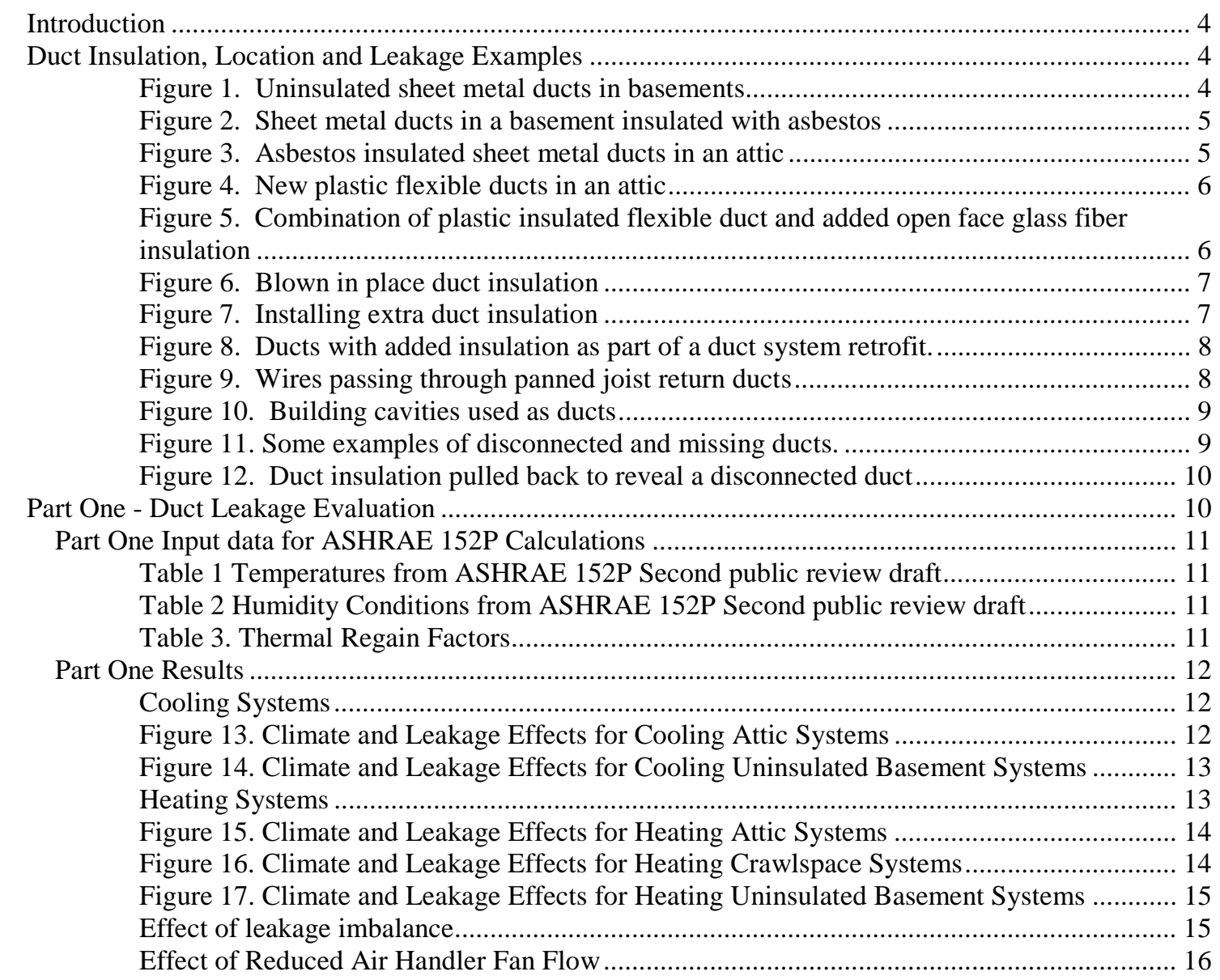

Part Two - Duct Insulation Evaluation ............................................................................... 16

Part Two Input data for draft ASHRAE 152P Calculations …................................................... 16

Part Two Results.............................................................................................................. 16

Cooling system efficiency sensitivity to duct insulation .................................................... 16

Figure 18. Climate and duct insulation effects for an Attic cooling system .......................... 17

Figure 19. Climate and duct insulation effects for a Basement cooling system ..................... 17

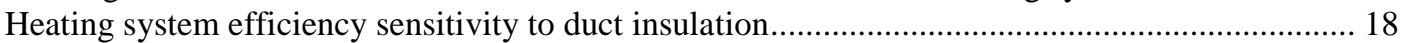

Figure 20. Climate and duct insulation effects for Heating Attic Ducts .............................. 19

Figure 21. Climate and duct insulation effects for Heating Basement Ducts ...................... 19

Figure 22. Comparison of distribution system efficiency changes by adding insulation to

typical (10\% supply and 10\% return leakage) and tight (5\% supply and 5\% return leakage)

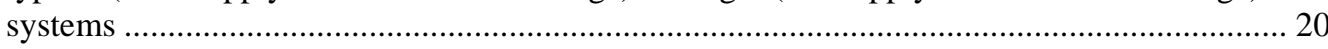

Reduced Capacity Equipment.................................................................................... 20

Figure 23. Changes in efficiency for multi-capacity attic systems …................................ 21

Figure 24. Changes in efficiency for multi-capacity basement systems .......................... 21

Design Condition Calculations for sensitivity to peak power availability and pricing ...................21

Figure 25. Climate and duct insulation effects on attic system efficiencies at design conditions

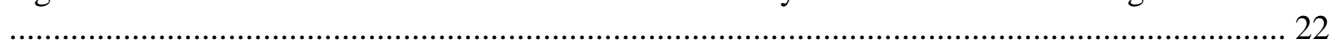

Figure 26. Climate and duct insulation effects on attic system efficiencies at design conditions

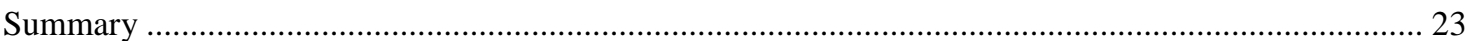

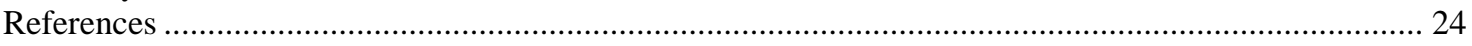

Appendix. Results of duct efficiency calculations........................................................................... 26

Table A1. Dependence of ASHRAE 152P Duct Efficiency on duct insulation at 10\% supply

and $10 \%$ return leakage ................................................................................................. 26 
Table A2. Dependence of ASHRAE 152P Duct Efficiency on duct insulation at 5\% supply

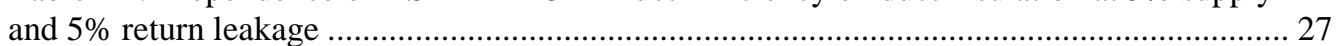

Table A3. Dependence of ASHRAE 152P Duct Efficiency on duct leakage ....................... 28

Table A4. Dependence of ASHRAE 152P Duct Efficiency on imbalanced duct leakage ....... 29

Table A5. Dependence of ASHRAE 152P Duct Efficiency on reduced fan flows $(320 \mathrm{cfm} / \mathrm{ton})$

Table A6. Dependence of ASHRAE 152P Duct Efficiency with half flow and half capacity

and $10 \%$ supply and 10\% return leakage ............................................................................ 31

Table A7. Dependence of ASHRAE 152P Design Duct Efficiency on duct insulation with

$10 \%$ supply and $10 \%$ return leakage................................................................... 32 


\section{Introduction}

This study was performed in order to find suitable efficiency and leakage specifications for Energy Star duct systems and provide recommendations on duct insulation specifications. This analysis looks at a typical house, with a selection of duct locations, climates, duct insulation (R-value), and duct leakage. A set of calculations were performed with reduced capacity and airflow to look at the effect of variable capacity systems. This was done to address concerns regarding the increased efficiency of multi-capacity equipment due to good part load performance and how these efficiency gains may be offset by increased duct losses. The duct system efficiencies were calculated using the procedures in proposed ASHRAE Standard 152P "Method of Test for Determining the Design and Seasonal Efficiencies of Residential Thermal Distribution Systems" (ASHRAE 1999). This proposed ASHRAE Standard can be used to calculate duct efficiency for both design and seasonal weather conditions. In this report, the seasonal efficiencies are used for most of the analysis because they are the most appropriate for estimating energy consumption in buildings. The effects at peak conditions are examined for changing duct insulation in order to provide preliminary estimates of the potential responses to time of use pricing.

The study was performed in two parts. The first part focused on duct leakage and the second part on duct insulation. The HVAC systems in the two parts share many attributes, however, they differ in detail and so are treated separately here. All the calculation results are summarized in tables in the Appendix, and specific results are given in the text.

\section{Duct Insulation, Location and Leakage Examples}

The following figures are examples of possible duct insulation, location and leakage. Usually ducts are only insulated if they are outside the conditioned space. Older duct systems made of sheet metal are often found in basements and have no insulation at all, as illustrated in Figure 1. In part one, the basement ducts are uninsulated, as shown in these examples.
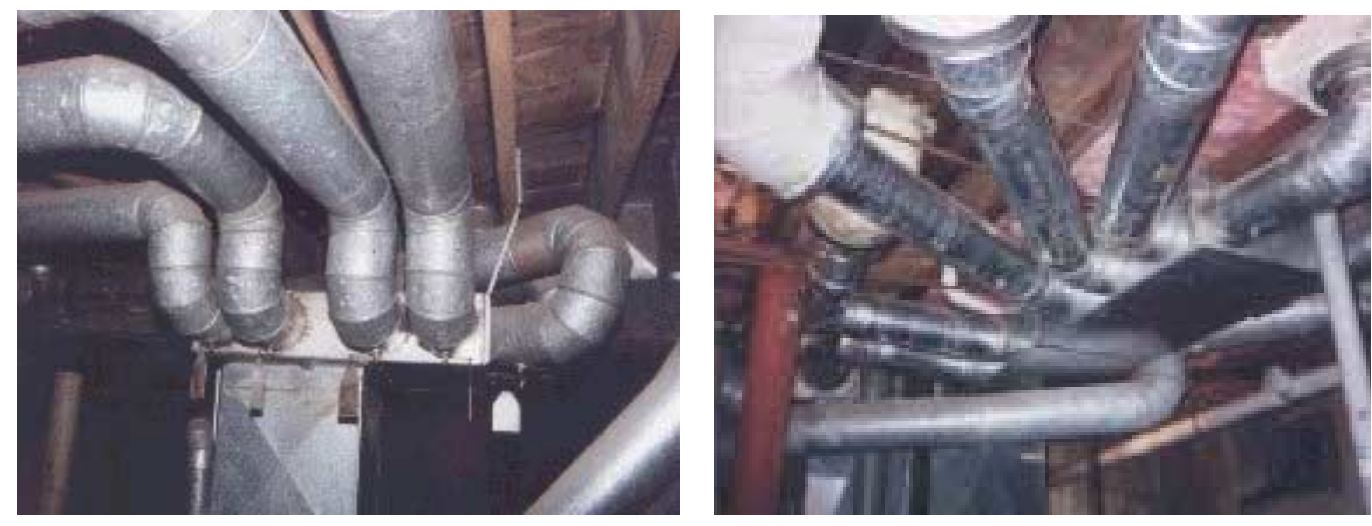

Figure 1. Uninsulated sheet metal ducts in basements

Some of these older sheet metal ducts have an asbestos based thin layer of insulation added to them, as shown in Figure 2. This thin layer of asbestos gives the ducts a small increase in thermal resistance to about R1.3 (including air films) compared to R1 for the air films on uninsulated ducts. 


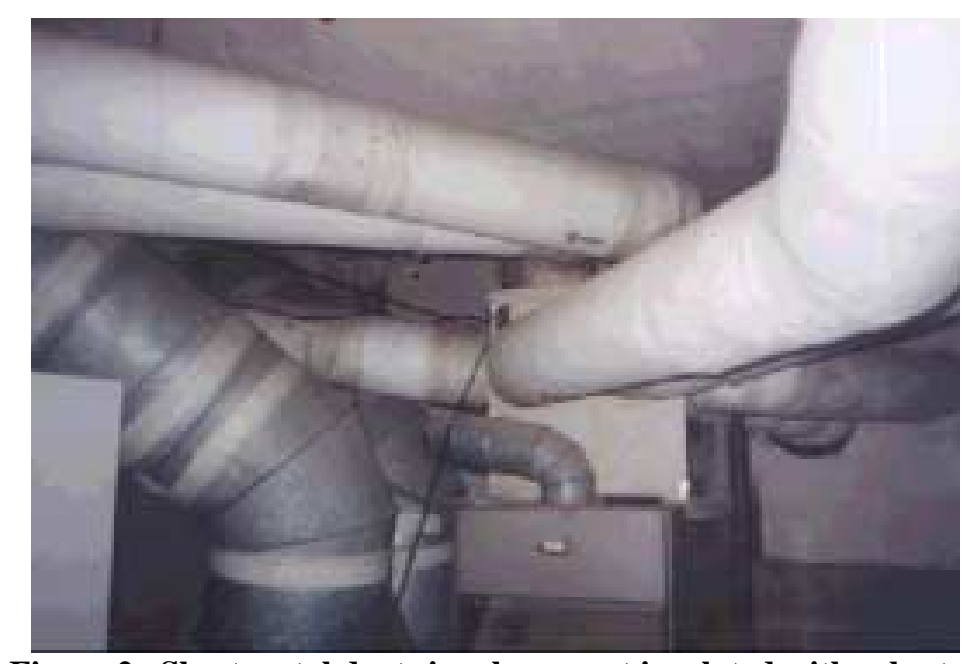

Figure 2. Sheet metal ducts in a basement insulated with asbestos

These asbestos insulated sheet metal ducts can also be found in unconditioned spaces. Figure 3 shows asbestos insulated sheet metal ducts (and supply plenum) in an attic.

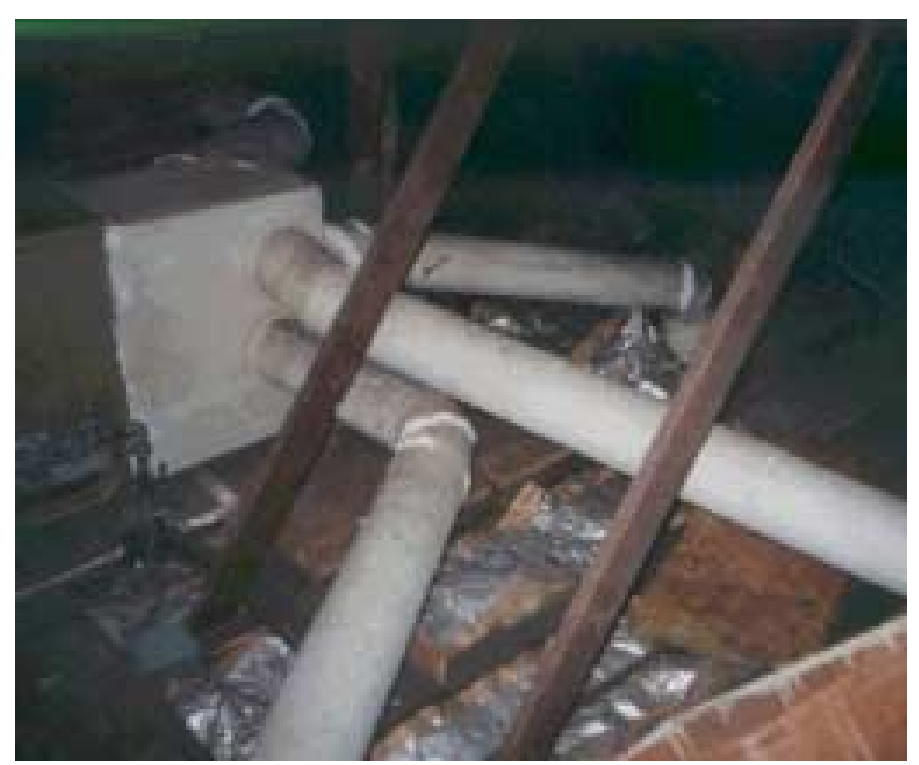

Figure 3. Asbestos insulated sheet metal ducts in an attic

Ducts in new houses are often made of flexible plastic duct as shown in Figure 4. This duct is usually labeled on the outside liner with its R-Value. Most ducts of this type have R4.2 insulation. These are the ducts used in attics in Part One of this study. 


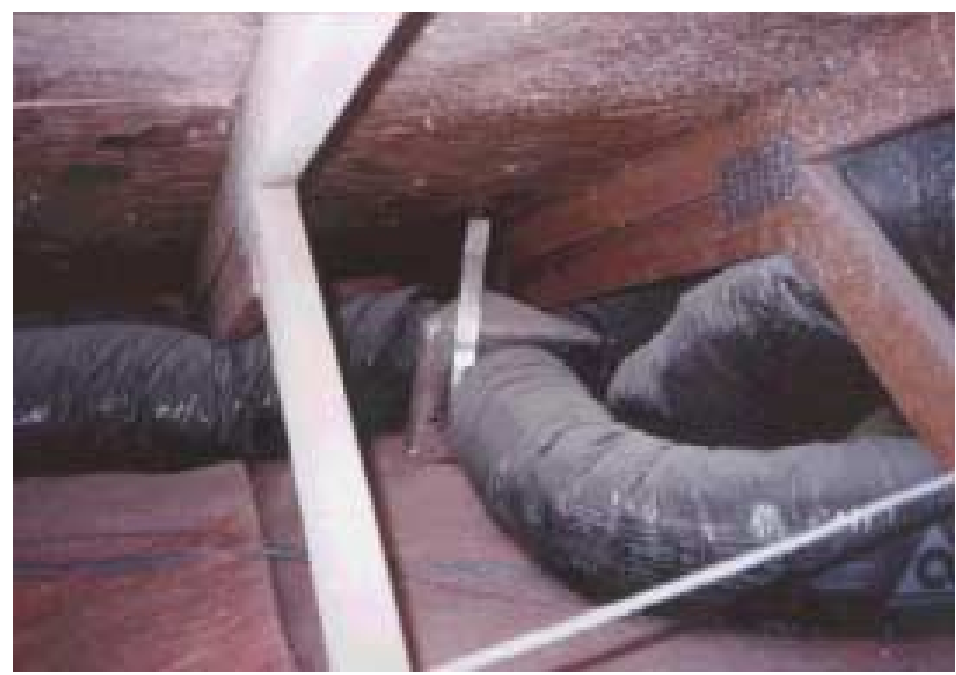

Figure 4. New plastic flexible ducts in an attic

In some cases a mixture of insulation will be seen. For example, open faced glass fiber insulation is often used around duct connections and plenums. Figure 5 shows plastic flexducts with added open face insulation around the register boots that go up through this basement ceiling. This open face insulation typically has less thermal resistance than the plastic flex duct. For ducts in crawlspaces in Part One this open face insulation was assumed to be used with an $\mathrm{R}$ vales half that of the plastic flexible duct, i.e. R2.1.

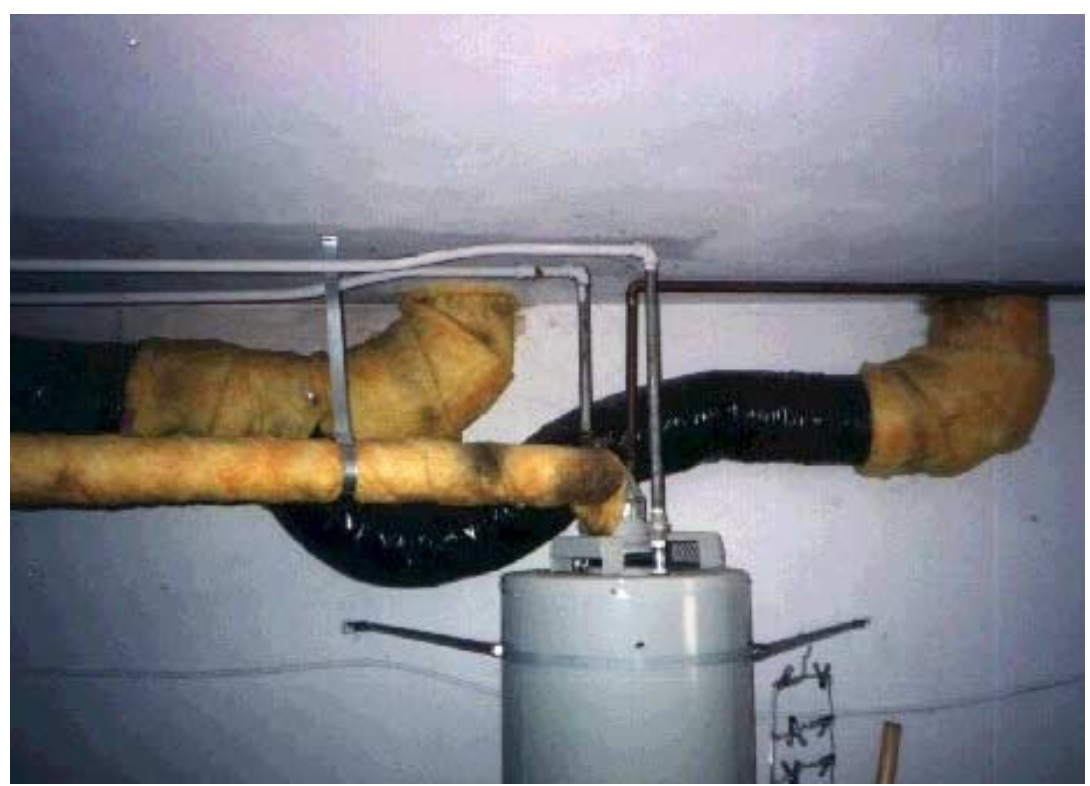

Figure 5. Combination of plastic insulated flexible duct and added open face glass fiber insulation

There are also less traditional methods of insulating ducts. In figure 6 the ducts are laid on the attic floor. They are then surrounded by cardboard channels and cellulose insulation in blown in around and over the ducts. 


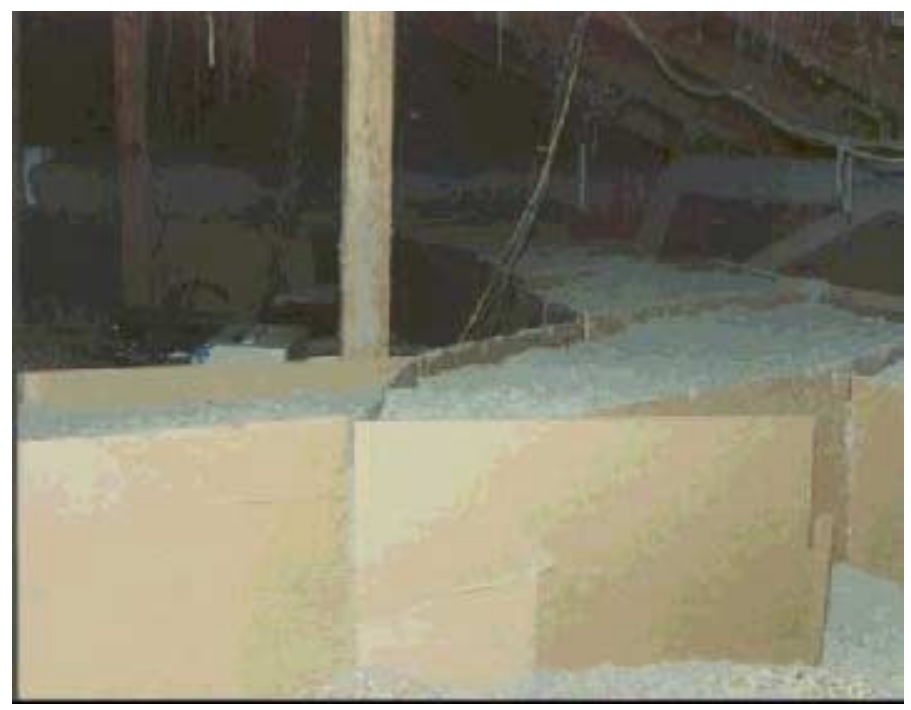

Figure 6. Blown in place duct insulation

When houses or heating/cooling systems are renovated, it is often cost effective to add insulation to existing ducts. In some cases this will be cheaper than replacing the ducts that are already installed. In addition, the potential for energy and cost savings can be significant, particularly when adding insulation to otherwise uninsulated ducts. The extra insulation reduces the heating and cooling losses from the ducts. Even when ducts are inside the living (conditioned) space these losses can be important because the temperature of the air in longer duct runs will change enough that the rooms they are conditioning will not receive enough heating or cooling. When ducts are insulated, an extra layer of insulation is added to the outside. Figure 7 shows ducts being wrapped in foil backed insulation (often called "duct wrap"). Figure 8 shows ducts after the added insulation is complete. In these cases the added insulation has a reflective foil exterior finish that is commonly used on these applications.

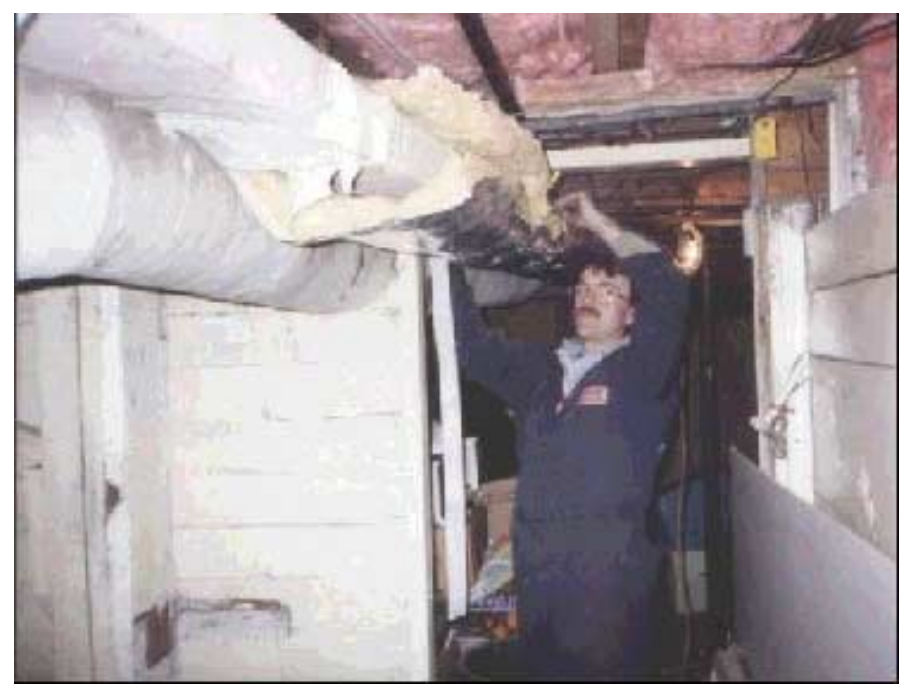

Figure 7. Installing extra duct insulation 

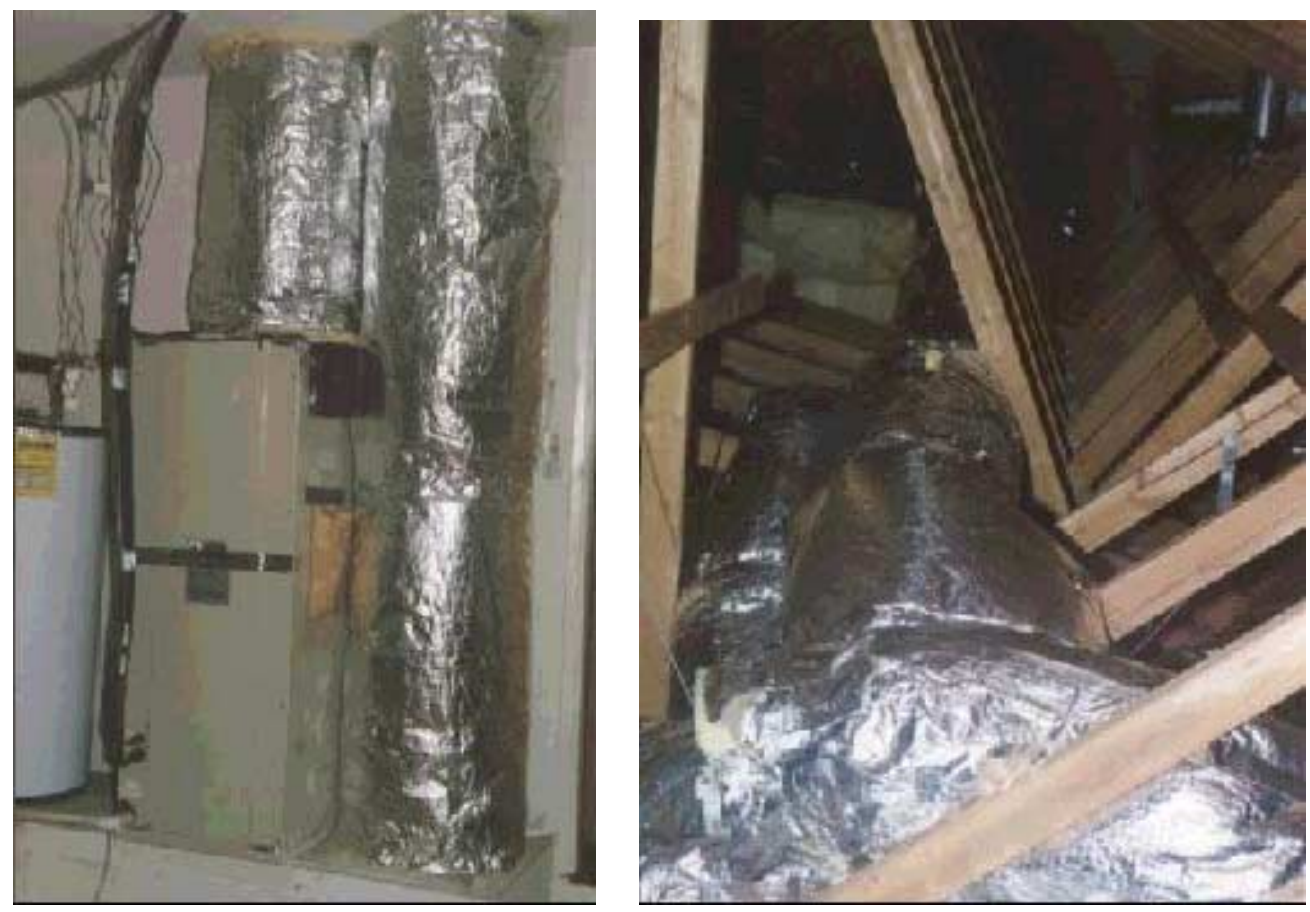

Figure 8. Ducts with added insulation as part of a duct system retrofit.

Duct leakage is common when parts of the walls or floor cavities used as ducts, e.g., spaces between ceiling or floor joists or internal wall stud spaces. Figure 9 shows basement joists that have been made into a duct using sheet metal "panning". In addition to the leakage at the unsealed sheet metal edges, these panned joists often have holes for plumbing or electrical wires/conduit. Usually it is the air returning to the furnace or air conditioner that flows through these ducts.
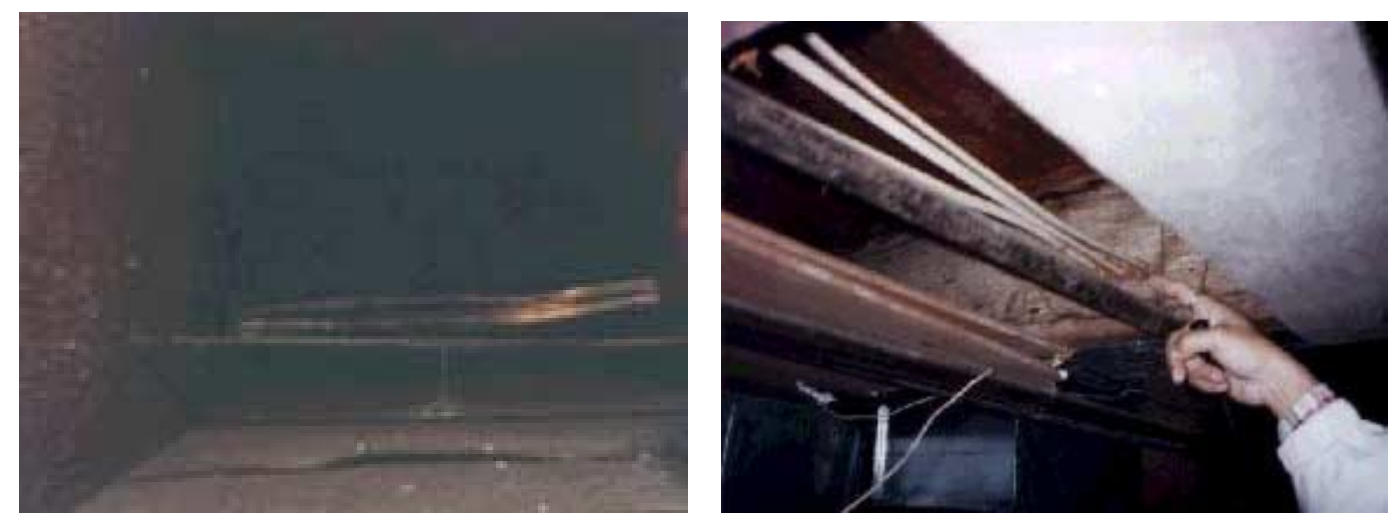

Figure 9. Wires passing through panned joist return ducts 

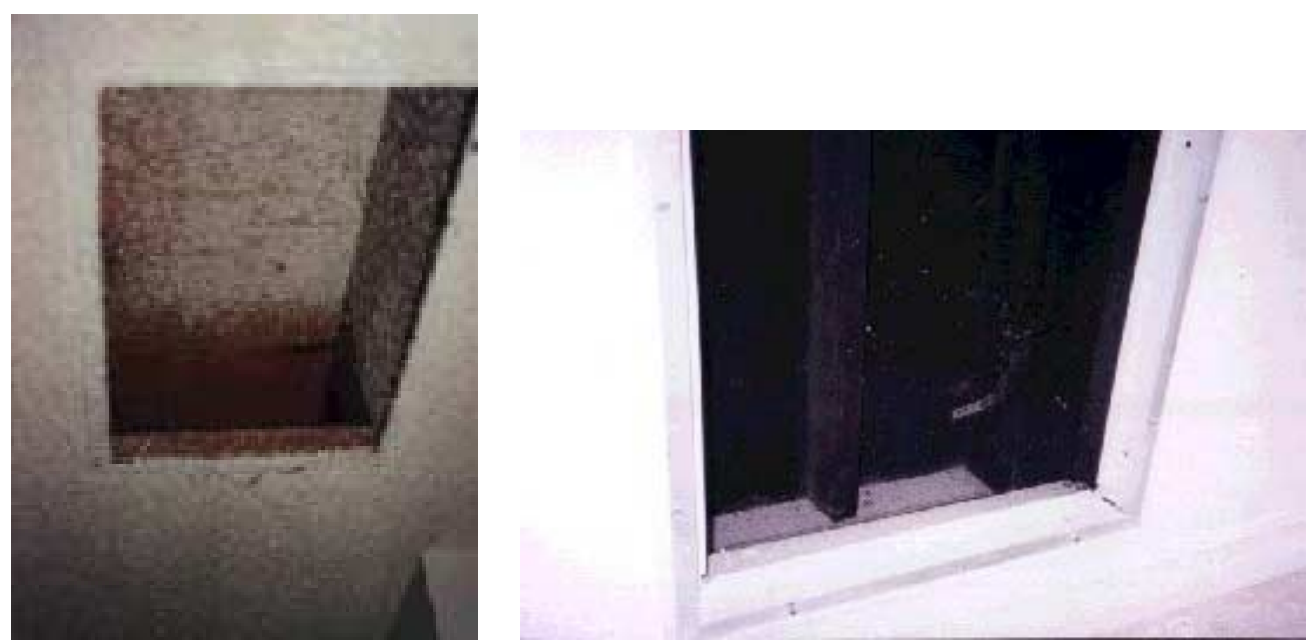

Figure 10. Building cavities used as ducts

In Figure 10, the register grilles have been removed to more clearly show how the building cavities are used as ducts. The picture on the left is of a ceiling where the space between the ceiling of this room and the floor of the room above is being used. The picture on the right is of an interior partition used as a duct. The building cavities are not sealed and field measurements have shown them to be significant sources of duct leakage.

Other significant duct air leakage occurs at disconnected or missing ducts as shown in Figure 11. In Figure 12 the disconnect was hidden underneath the duct insulation. This illustrates that not all duct leaks can be found by simple observation.
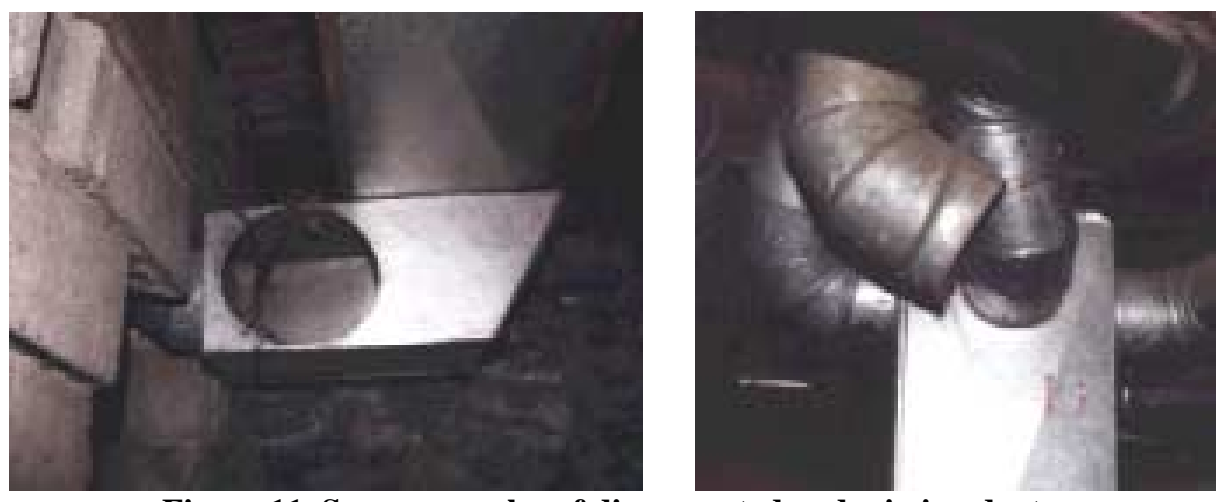

Figure 11. Some examples of disconnected and missing ducts. 


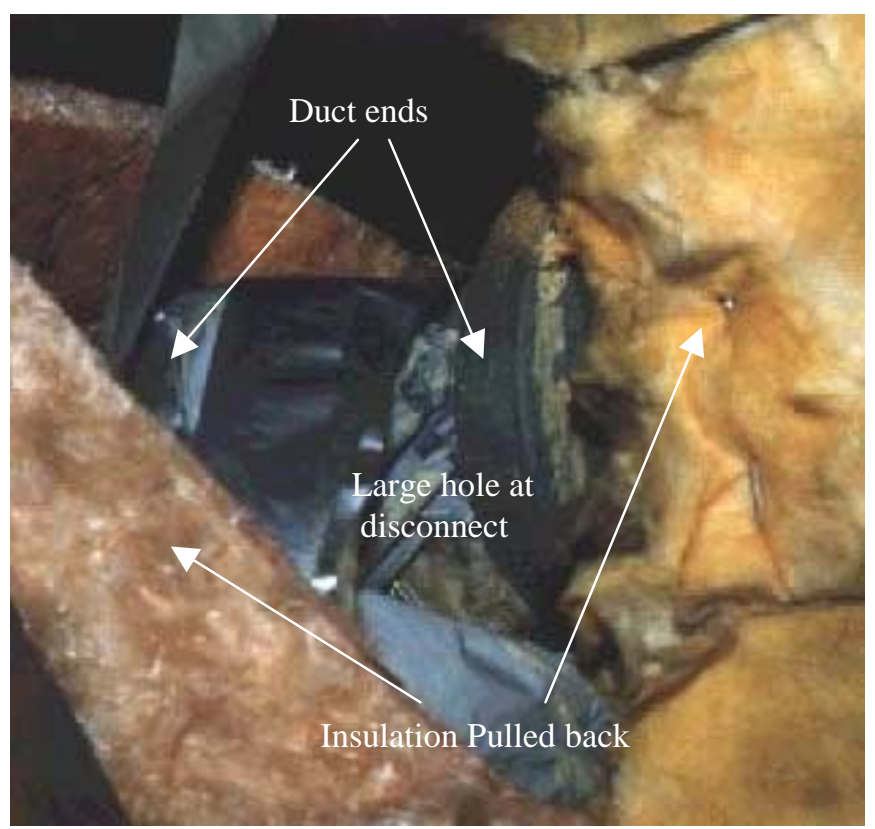

Figure 12. Duct insulation pulled back to reveal a disconnected duct

\section{Part One - Duct Leakage Evaluation}

Part one concentrates on the effects of duct leakage on duct system efficiency (DSE). This part of the study was performed in conjunction with the Environmental Protection Agency (EPA) in order to provide technical background for the EPA Energy Star ducts program. This EPA program includes recommendations for acceptable duct leakage, insulation and $152 \mathrm{P}$ efficiency in order to have a minimum acceptable level of duct system performance.

Six climates were chosen to represent a wide range of weather conditions:

- Miami, FL (warm and humid)

- Phoenix, AZ (hot/cold and dry)

- Sacramento, CA (moderate and dry)

- Washington, D.C. (moderate and humid)

- Minneapolis, MN (cold and dry)

- Seattle, WA (cool and humid)

The duct locations were chosen to represent common duct locations:

- Attic

- Attic with a radiant barrier (ducts below radiant barrier)

- Uninsulated Crawlspace

- Uninsulated Basement

The duct leakage was tested at three levels (the duct leakage is expressed as a percentage of fan flow):

- $5 \%$ supply and 5\% return - a system tighter than average

- $10 \%$ supply and $10 \%$ return - a typical system

- $14 \%$ supply and $14 \%$ return - a poorer than average system

The tighter than average systems are at a leakage level that is easily achievable in new construction without changing duct construction and sealing techniques. Six new houses tested by LBNL (Walker et al. 1999) had average leakage at this level. Also, older houses that have their ducts sealed (e.g., Walker et al. 1997) 
can have their leakage reduced to these levels. The typical system leakage is based on tests in new houses, including those summarized in Walker (1998) and Modera and Wilcox (1995). The poorer system is typical of existing homes and is the default value used in the California State Energy Code (CEC (1998)).

Additional tests were performed to examine the effects of unbalanced leakage (where the supply and return leakage are not the same) and reduced air handler flow. The unbalanced leakage was tested for two cases: one with more supply than return (15\% supply, $5 \%$ return) and more return than supply (5\% supply and $15 \%$ return) whilst maintaining the same total $(20 \%)$ leakage as the typical system. The reduced fan flow tests were performed for cooling systems only, where the air handler flow was set to $320 \mathrm{cfm} / \mathrm{ton}$ (this is considerably less then manufacturers' recommend flows that are typically $400 \mathrm{cfm} / \mathrm{ton}$ ) and in the $152 \mathrm{P}$ calculations the reduction in equipment efficiency due to reduced flow was also included.

\section{Part One Input data for ASHRAE 152P Calculations}

The temperature of the duct surroundings determines the conduction (and return leakage) energy losses. This, in turn depends on the local climate. The climate data used in this study are given in Tables 1 and 2 and are taken from the second public review draft of ASHRAE standard 152P (ASHRAE 2001). The data in these tables illustrate the wide range of climatic (and therefore duct location) conditions that are used for the duct efficiency calculations.

\begin{tabular}{|l|c|c|c|c|c|}
\hline \multicolumn{6}{|c|}{ Table 1 Temperatures from ASHRAE 152P Second public review draft } \\
\hline \multicolumn{1}{|c|}{ City } & State & $\begin{array}{c}\text { Heating } \\
\text { design }\end{array}$ & $\begin{array}{c}\text { Heating } \\
\text { Seasonal }\end{array}$ & $\begin{array}{c}\text { Cooling } \\
\text { Design }\end{array}$ & $\begin{array}{c}\text { Cooling } \\
\text { seasonal }\end{array}$ \\
\hline Phoenix & AZ & 38 & 49 & 107 & 91 \\
\hline Sacramento & CA & 33 & 48 & 97 & 86 \\
\hline Washington & DC & 20 & 37 & 93 & 81 \\
\hline Miami & FL & 50 & 54 & 90 & 80 \\
\hline Minneapolis & MN & -11 & 24 & 88 & 81 \\
\hline Seattle & WA & 28 & 44 & 81 & 78 \\
\hline
\end{tabular}

\begin{tabular}{|l|c|c|c|c|c|c|c|c|c|}
\hline \multicolumn{8}{|c|}{ Table 2 Humidity Conditions from ASHRAE 152P Second public review draft } \\
\hline & & \multicolumn{9}{|c|}{ Humidity Ratio } \\
\hline \multicolumn{1}{|c|}{ City } & State & $\begin{array}{l}\text { Outside } \\
\text { design }\end{array}$ & $\begin{array}{l}\text { Outside } \\
\text { seasonal }\end{array}$ & $\begin{array}{l}\text { Inside } \\
\text { design }\end{array}$ & $\begin{array}{l}\text { Inside } \\
\text { seasonal }\end{array}$ & $\begin{array}{l}\text { Outside } \\
\text { design }\end{array}$ & $\begin{array}{l}\text { Outside } \\
\text { seasonal }\end{array}$ & $\begin{array}{l}\text { Inside } \\
\text { design }\end{array}$ & $\begin{array}{l}\text { Inside } \\
\text { seasonal }\end{array}$ \\
\hline Phoenix & AZ & 0.0085 & 0.0079 & 0.0074 & 0.0071 & 35 & 31 & 27 & 27 \\
\hline Sacramento & CA & 0.0081 & 0.0086 & 0.0072 & 0.0074 & 32 & 30 & 27 & 27 \\
\hline Washington & DC & 0.0147 & 0.0137 & 0.0099 & 0.0095 & 39 & 35 & 30 & 29 \\
\hline Miami & FL & 0.0171 & 0.0160 & 0.0109 & 0.0104 & 40 & 37 & 31 & 30 \\
\hline Minneapolis & MN & 0.0129 & 0.0125 & 0.0092 & 0.0090 & 35 & 33 & 29 & 29 \\
\hline Seattle & WA & 0.0092 & 0.0084 & 0.0077 & 0.0074 & 29 & 28 & 27 & 27 \\
\hline
\end{tabular}

Another factor depending on duct location is the regain of duct losses caused by the duct losses changing the temperature of the space they are located in. In the 152P calculation procedure, this is represented by the thermal regain factor. The regain data in Table 3 are from appendix $\mathrm{H}$ in the first public review draft of ASHRAE 152P (ASHRAE 1999).

Table 3. Thermal Regain Factors

\begin{tabular}{cc}
\hline Location & $\begin{array}{c}\text { Thermal Regain Factor } \\
{\left[\mathbf{F}_{\text {regain }}\right]}\end{array}$ \\
\hline Attic & 0.10 \\
Uninsulated Crawlspace (Vented) & 0.50 \\
Uninsulated Basement & 0.50
\end{tabular}

\section{House Data:}

- Floor area: $2000 \mathrm{ft}^{2}, 2$ story, 2 returns.

- Duct Surface area from 152P defaults: Supply $=340 \mathrm{ft}^{2}$, Return $=80 \mathrm{ft}^{2}$.

- Duct Locations: Attic (vented), attic (vented) with cool roof/radiant barrier temperature reduction credit, crawlspace (uninsulated and vented), uninsulated basement. 
- Duct insulation: R4.2 for attics, R2.1 for crawlspace and R1 (this represents the air film resistance only. There is no specific insulation material) for basement ducts.

- Fan flow: based on defaults from California State Energy Code (CEC 1998): for heating $=0.5 \mathrm{cfm} / \mathrm{ft}^{2}$ gives $1000 \mathrm{cfm}$. For cooling $=0.7 \mathrm{cfm} / \mathrm{ft}^{2}$ gives $1400 \mathrm{cfm}$.

- Equipment capacity: heating capacity $=60 \mathrm{kBtu} / \mathrm{hour}$ (assuming the temperature rise across the heat exchanger of $55^{\circ} \mathrm{F}$ ), cooling capacity $=3.5$ tons (assuming $400 \mathrm{cfm} / \mathrm{ton}$ ). Cooling equipment has orifice type control system.

- Minimum flow specification for EPA Energy Star ducts: At $320 \mathrm{cfm} / \mathrm{ton}, 3.5$ tons gives $1120 \mathrm{cfm}$. Also, the non-ACCA (ACCA (1997)) design penalties for equipment performance were also invoked in the simulations. This lower flow results in an $8 \%$ reduction in efficiency for cooling equipment and different duct leakage losses.

\section{Part One Results}

The results show how the distribution system efficiency (DSE) depends on climate and duct location. Even at the lowest duct leakage level the DSE ranges from $75 \%$ to $81 \%$ due to the remaining duct leakage and the conduction losses from the ducts. In general, attic duct systems are more sensitive to climate and duct leakage than basement duct systems. In addition, the more extreme the climate, the stronger the effect of leakage so that for cooling the ducts in Miami show the greatest variation and Seattle the least. Conversely, for heating the Minneapolis duct systems show the greatest variation and Sacramento, the least. In the following discussion, all the percentages are distribution system efficiency percentages, not fractions of the predicted efficiency. For example, a change in cooling efficiency from $59 \%$ to $76 \%$ by reducing leakage from $28 \%$ to $10 \%$ in Miami (see Figure 13) is expressed as the simple difference in DSE: $76 \%-59 \%=17 \%$ NOT as a fractional change: $(76 \%-59 \%) / 76 \%=22 \%$.

\section{Cooling Systems}

For cooling systems, the following results are for the worst place to put ducts (an attic with no radiant barrier) and for a benign duct location (an uninsulated basement). In Figure 13 the results are presented for attic cooling systems. The climate changes the DSE by $6 \%$ for the tight ducts. This is increased to a $11 \%$ spread for the leaky ducts. This shows that the leaky ducts are more sensitive to climate variations than the tight ducts. Similarly, the range of efficiencies in each climate is greater for hotter climates: for the leaky ducts the range is $17 \%$ in Miami and 11\% in Seattle.

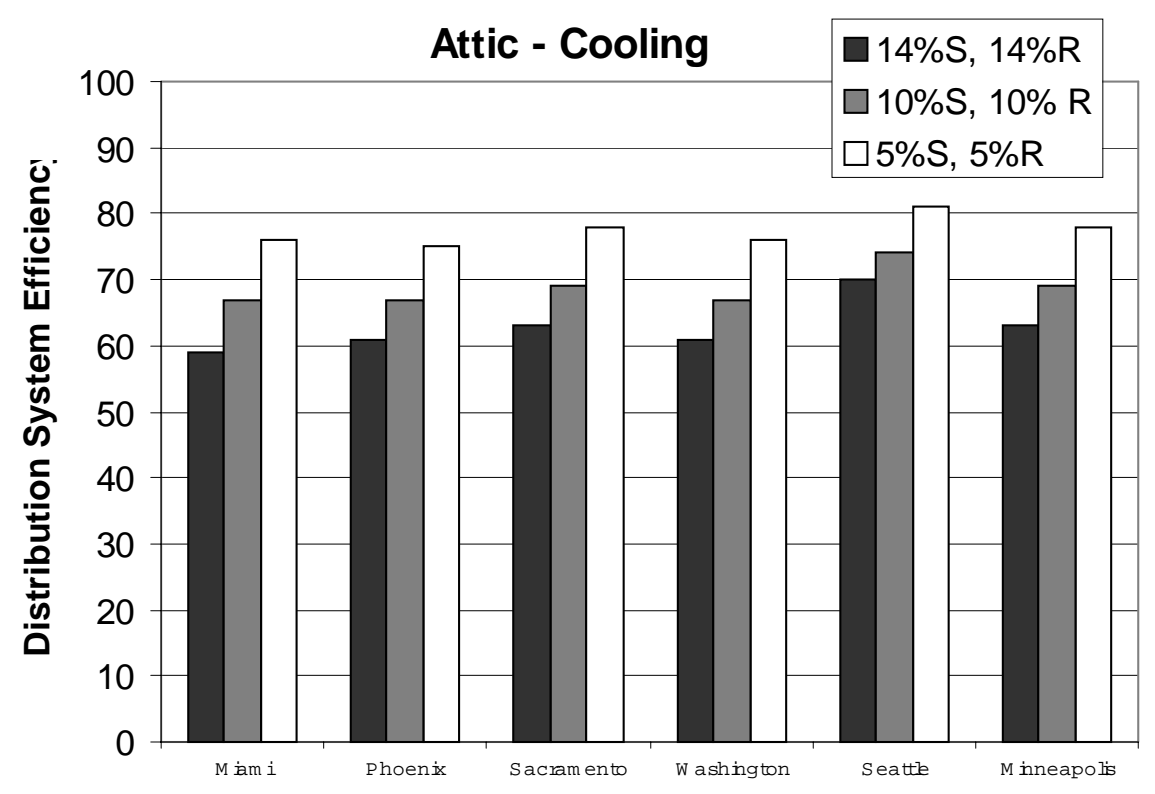

Figure 13. Climate and Leakage Effects for Cooling Attic Systems 


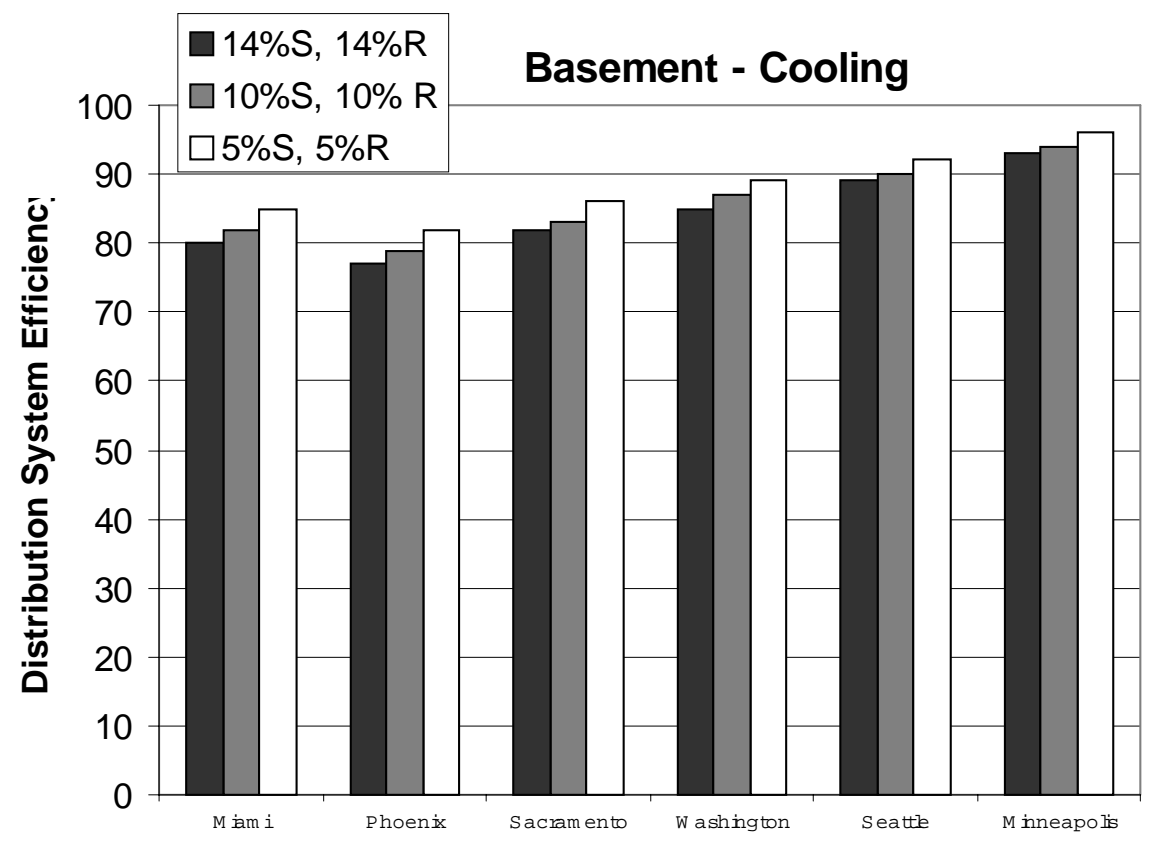

Figure 14. Climate and Leakage Effects for Cooling Uninsulated Basement Systems

Comparing the results in Figures 13 and 14 shows that changing duct location from attic to basement significantly increases the efficiency by an average of $17 \%$ for typical systems. The basement systems can be very efficient (exceeding 95\% for Minneapolis) because the basements are cooler than the attics. Averaged over all six cities, the basement temperatures were $24^{\circ} \mathrm{F}$ cooler than the attics and the enthalpy was $9 \mathrm{Btu} / \mathrm{lb}$ less. Even for the tight ducts, in Miami, the efficiency increased from $76 \%$ to $85 \%$ by moving the ducts from the attic to the basement (the poor ducts show a greater sensitivity, changing from $59 \%$ to $80 \%$ ). The basement duct systems show less sensitivity to leakage changes than the attic duct systems. The different leakage levels only change the basement results by about two percent for any given climate compared to about seven percent for attic systems.

Additional calculations for attics with Cool Roof/Radiant Barrier temperature reduction credit show an increase in DSE of about $4 \%$ for leaky ducts and $2.5 \%$ for tight ducts. The difference is greatest in Phoenix at $6 \%$ for leaky ducts, but only $2 \%$ in Seattle. This is because the credit acts to reduce the extreme attic temperatures and so it has a bigger effect in more extreme climates.

The crawlspace results are much like basements. The major difference is that the climates that get cool in winter and therefore have low average ground temperatures (Washington, Seattle and Minneapolis) and cooler basements. This results in higher cooling efficiencies for basements (by about 6\%) and lower heating efficiencies (by about 10\%) for a typical system. In these climates the optimum duct location will depend on how much energy is used to heat or cool the house. A predominantly heating system will be better in an uninsulated crawlspace than an uninsulated basement and visa-versa for a predominantly cooling system. Note that these results will change significantly if the crawlspace or basement are insulated either with respect to outside (increasing efficiency) or with respect to the house (generally decreasing efficiency). For example, an insulated to outside basement in Minneapolis (that essentially becomes conditioned space) will have a better heating efficiency than an uninsulated crawlspace.

\section{Heating Systems}

The results in Figure 15 show that the heating systems in attics are equally sensitive to both climate and leakage as the cooling systems. The variation due to leakage is about $10 \%$, ranging from $8 \%$ in Miami to $11 \%$ in Minneapolis. The variation due to climate for the same leakage level is about the same magnitude, ranging from $12 \%$ for leaky ducts to $9 \%$ for tight ducts. In Figure 16, the crawlspace systems show overall higher DSEs than for the attic systems in Figure 15, with less dependence on leakage and climate. The 
change in DSE with climate is only $5 \%$ for a typical leakage crawlspace systems, and leakage effects are fairly small (6\% at most). The basement results lie between the attic and crawlspace as shown in Figure 17.

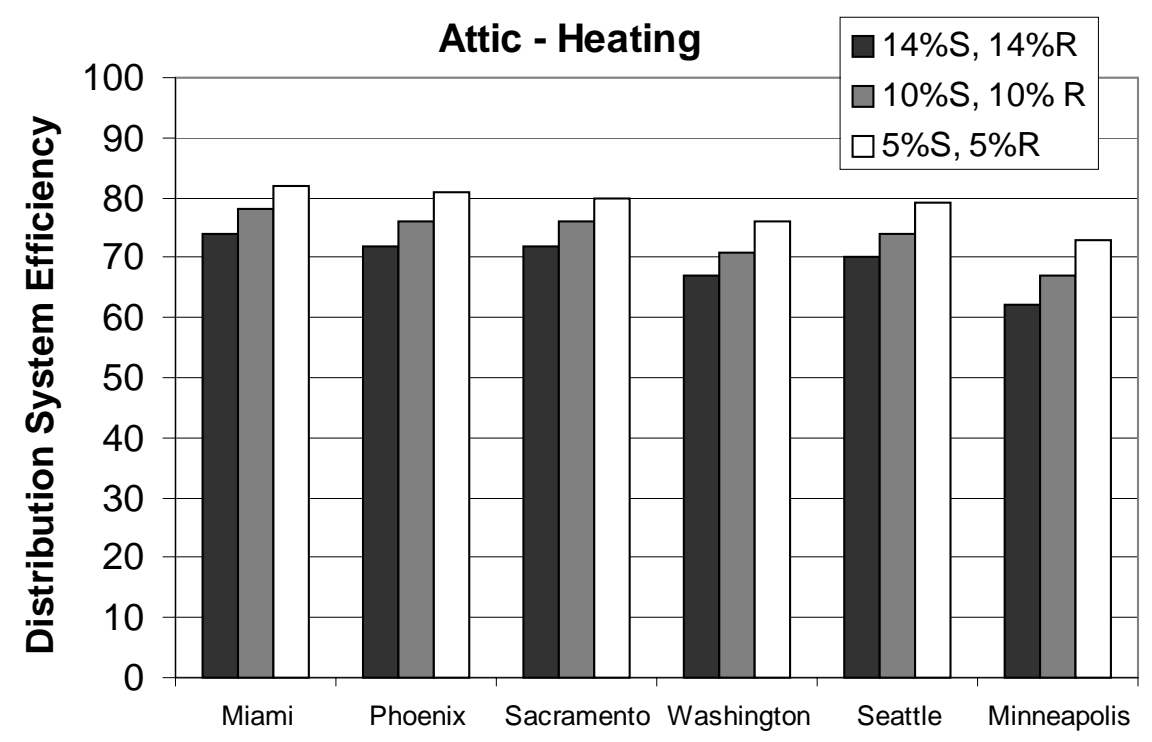

Figure 15. Climate and Leakage Effects for Heating Attic Systems

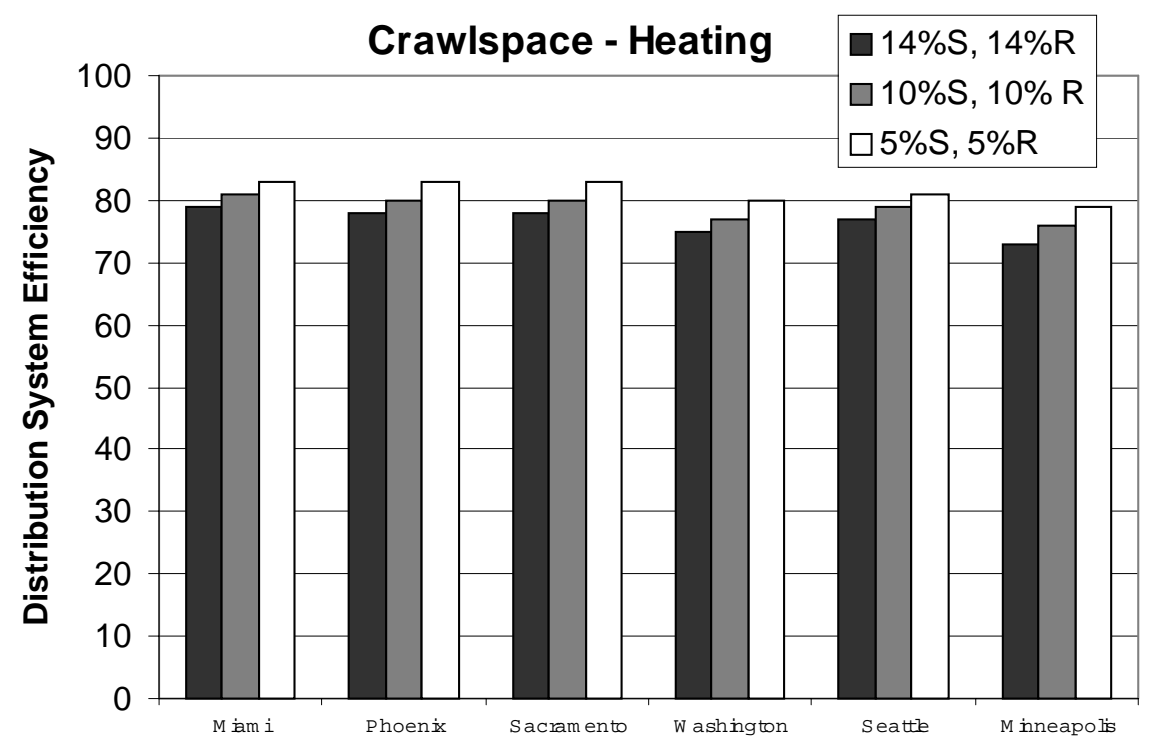

Figure 16. Climate and Leakage Effects for Heating Crawlspace Systems 


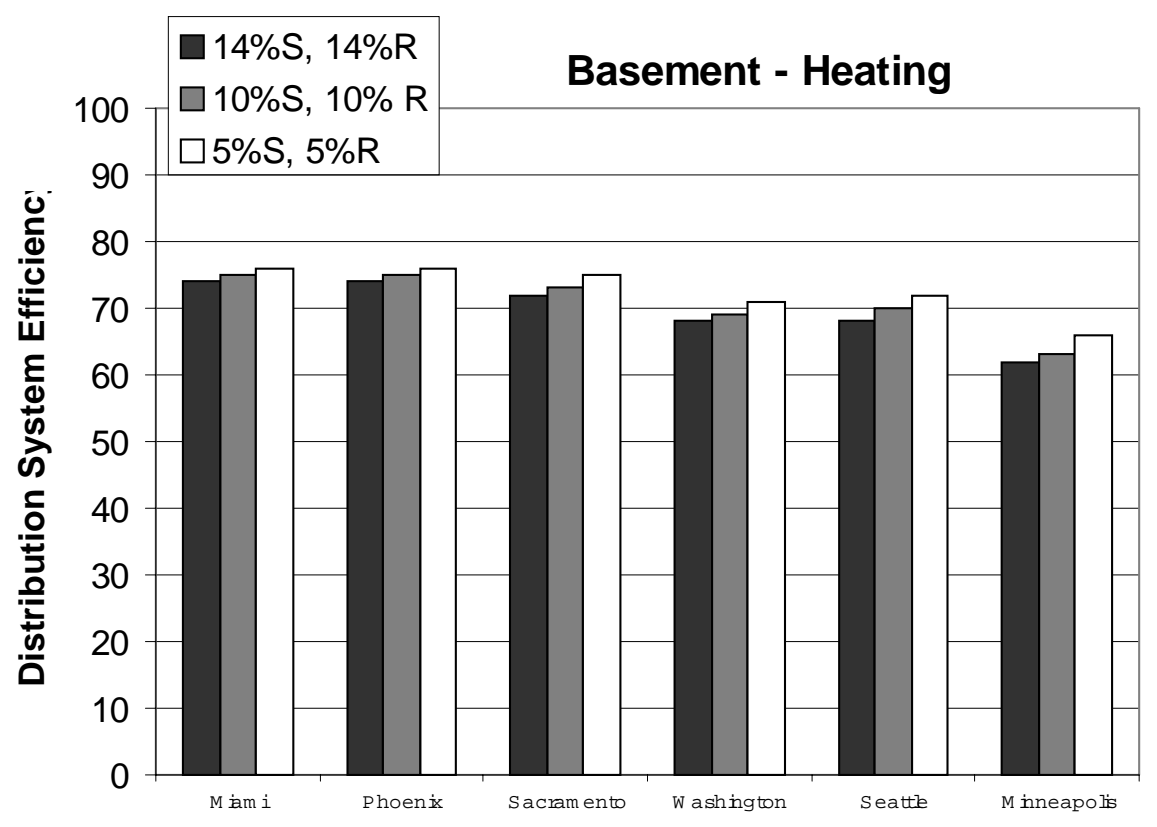

Figure 17. Climate and Leakage Effects for Heating Uninsulated Basement Systems

\section{Effect of leakage imbalance}

The effects of supply and return duct leakage on energy losses for the duct system are not the same. Supply leakage represents a loss of efficiency proportional to the leakage fraction. For return leaks, the effect depends on the temperature and humidity of the air entering the leaks. If this is hot humid air from an attic in the summer then the effect on efficiency can be proportionally larger than the leakage (e.g., a 10\% return leak may reduce the efficiency by $15 \%$ ). Similarly, if the ducts are in a cool location in the summer, then cool air enters the return leaks and the return leak effect is reduced (e.g., a 10\% leak has a $5 \%$ effect on efficiency). The imbalance tests were done in two extreme climates: Miami and Minneapolis.

In addition, the 152P calculations include changes in building heating and cooling load due to changes in building infiltration rate caused by the duct leakage imbalance. Excess supply leakage tends to depressurize the house and increase building infiltration load. Conversely, excess return leakage results in a pressurized house with reduced infiltration loads. For the cases given here, the assumed basic infiltration rate of 0.35 air changes per hour corresponds to about $95 \mathrm{cfm}$. The $10 \%$ fan flow imbalance corresponds to $100 \mathrm{cfm}$ for heating and $140 \mathrm{cfm}$ for cooling. Therefore, the infiltration load can be more than doubled for the system with excess supply leakage and completely eliminated for the excess return leakage case. The change in infiltration load is expressed as a fraction of the total building load (estimated by multiplying the equipment capacity by the delivery effectiveness in 152P) in order to determine its effect on the DSE. In this way, addition building infiltration caused by duct leakage decreases the DSE and conversely, reduced infiltration load increases the DSE. For example, if the basic infiltration load is a quarter of the building total load and the infiltration load is doubled due to excess supply leakage, then the DSE is reduced by a quarter.

For cooling, the excess supply leakage reduces the efficiency by an average of $6 \%$, with the biggest effect for the basement ducts and the smallest effect for the attic ducts. The excess return leakage results in an average efficiency increase of 6\%, also with less effect on attics than basements. The basements have a greater effect because cool air is drawn from the basement into the return and the infiltration imbalance has less warm outside air entering through the house envelope because of this inflow of cool basement air.

Imbalance calculations were also performed for heating. The effects were almost the same for heating and cooling. The excess supply leakage reduces the efficiency by an average of $6 \%$, with the effect for 
Minneapolis about double that for Miami due to its cold climate. The excess return leakage results in an average increase of $8 \%$, also with greater effect in Minneapolis than Miami.

\section{Effect of Reduced Air Handler Fan Flow}

These calculations used $320 \mathrm{cfm} /$ ton rather than the $400 \mathrm{cfm} /$ ton used in the other cooling calculations. This flow reduction is typical of those found in existing HVAC systems. Because the leakage scaled with the air handler fan flow the main effects of this reduction are the increased conduction losses and equipment effects. The increased conduction losses are because the same size ducts were used with the reduced flows leading to increased residence time in the ducts. The equipment factor in $152 \mathrm{P}$ includes the effect on equipment efficiency of reduced flows.

The reduced fan flow calculations were performed for cooling for all duct locations and all climates. The reduced fan flow generally reduced the DSE by about $4 \%$ on average. The cooler climates and locations showed about $1 \%$ greater DSE reduction and the warmer climates and duct locations showed reduced sensitivity with $1 \%$ less DSE reduction.

\section{Part Two - Duct Insulation Evaluation}

In this second part of the study the focus is moved from duct leakage (covered in Part one) to duct insulation. The same six climates and three duct locations as in Part one were used on Part two. The duct insulation was fixed at four levels representing the most likely insulation levels to be found in existing duct systems and insulation levels that are likely to be used in new systems or systems being retrofitted. The insulation is specified by its thermal resistance. The industry standard is to use the $R$ value of the insulation. Almost all duct insulation is made from glass fiber and a thicker layer of glass fiber has greater insulating effect and higher $\mathrm{R}$ value.

- R2. This represents the minimum insulation level that could be achieved by simply wrapping ducts in a thin layer of open faced glass fiber insulation (i.e. there is nothing to encapsulate or hold the insulation in place). Figure 5 shows an example of this type of insulation where it is applied to uninsulated duct fittings. Note that this is not the same as the uninsulated basement ducts from Part one.

- R4.2. This is a common insulation level found in most installations using insulated plastic flex duct. This is illustrated in Figures 4 and 5.

- R6. Some insulated plastic flex duct is currently used with this amount of insulation in new construction. The insulation being added in Figures 7 and 8 is foil backed R6.

- R8. This is the practical upper limit for duct insulation because the added duct size (about 125$150 \mathrm{~mm}$ or 5 to 6 inches) makes it difficult to install in the small spaces allowed in houses for HVAC systems. The additions to the duct diameter for this level of insulation makes it difficult to add to existing duct systems for retrofits.

\section{Part Two Input data for draft ASHRAE 152P Calculations}

Part two uses the same house and duct system characteristics as in Part one that are summarized in Tables 1,2 and 3.

\section{Part Two Results Cooling system efficiency sensitivity to duct insulation}

Figures 18 and 19 show how the cooling duct efficiency varies with duct insulation, climate and duct location. The figures show that the maximum benefit of duct insulation is gained when ducts are in more extreme locations where losses are the greatest. For cooling, the extreme location is the attic. For the attic systems the efficiencies were increased by an average of $16 \%$ compared to only $3 \%$ for basement systems by increasing R-value from R2 to R8. The greatest change of $19 \%$ was for the attic system in Phoenix and the smallest change was $1 \%$ for the basement system in Minneapolis. The largest changes in efficiency are also the largest fractional changes in energy use - for the Phoenix case, the attic cooling system would use 
$35 \%$ less energy with $\mathrm{R} 8$ rather than $\mathrm{R} 2$ insulation. This is because the less efficient systems have the highest conduction energy losses that are affected by the added insulation. For the crawlspace systems, the average change from R2 to R8 was 5\% because the crawlspaces are cooler then the attics (but not quite as cool as a basement). These results indicate that retrofit programs or new home specifications for better duct insulation for cooling ducts should concentrate on ducts in attics.

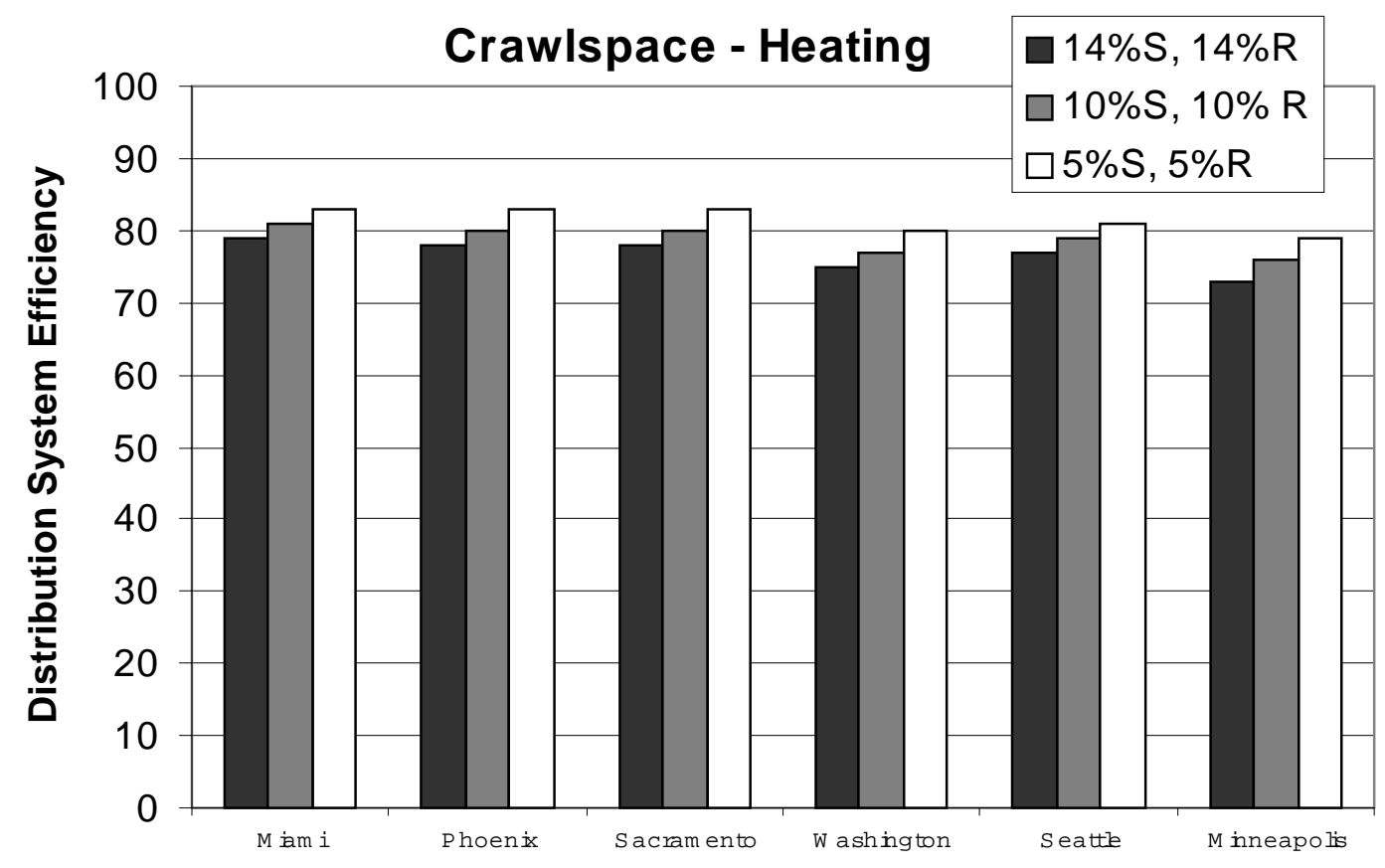

Figure 18. Climate and duct insulation effects for an Attic cooling system

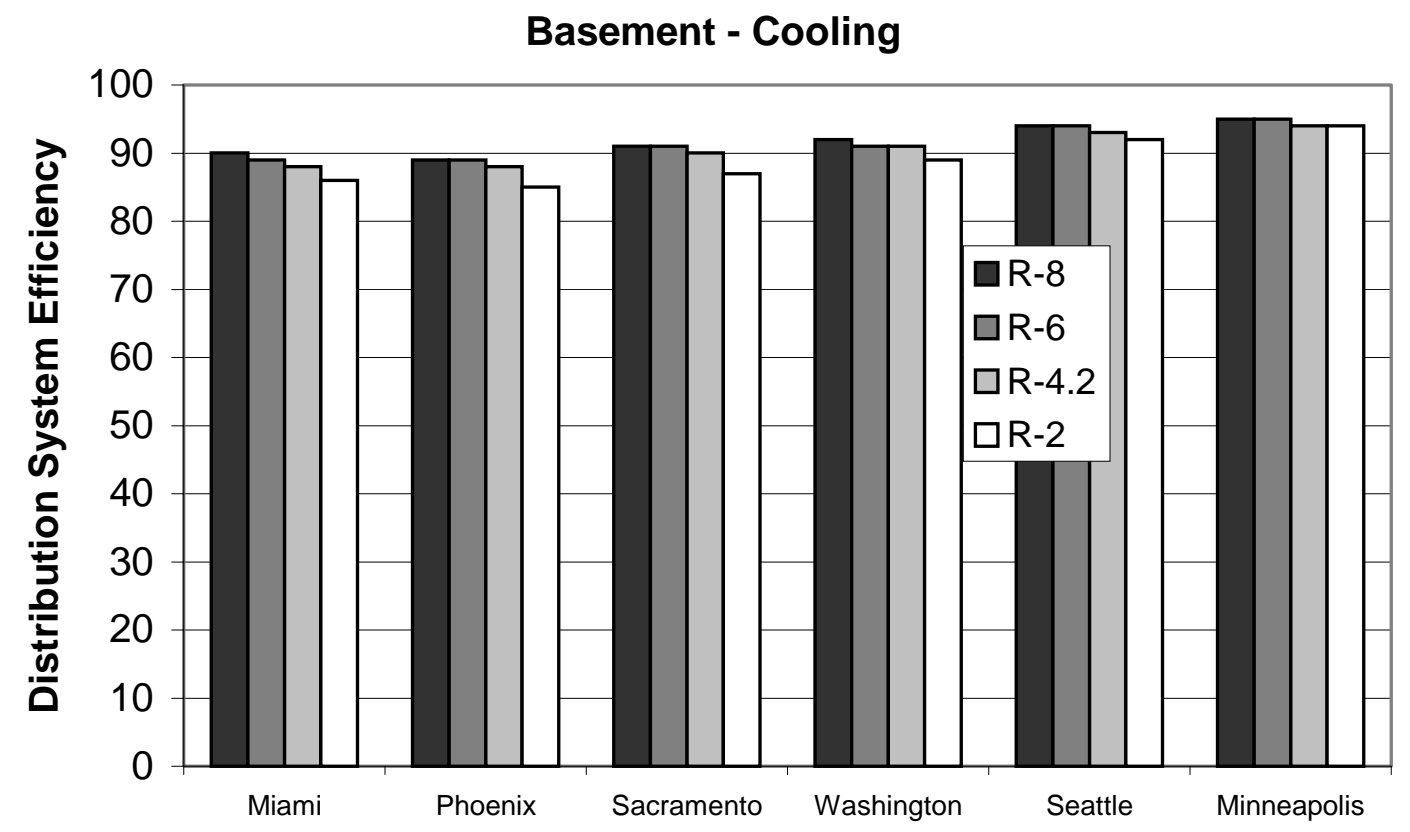

Figure 19. Climate and duct insulation effects for a Basement cooling system 
As insulation is added in steps from $\mathrm{R} 2$ to $\mathrm{R} 8$ there are diminishing returns with each step. Because the changes are small except for the attic systems, the following results are for attics only. Changing from R2 to R4.2 increases duct efficiency by an average of $11 \%$ ( $19 \%$ less energy consumed). Adding another R2 (for a total of R6) only makes an additional $3 \%$ change (4\% less energy consumed). Going to R8 from R6 only makes a $2 \%$ reduction ( $3 \%$ less energy consumed). The average fractional change in energy consumption form adding insulation beyond the typical R4.2 standard found in many systems was about $4 \%$ for R6 and 7\% for R8. For less insulated ducts (starting at R2 - more typical of older systems) the fractional increase in energy efficiencies (corresponding to changes in energy consumption) are greater, at about $19 \%$ to $\mathrm{R} 4.2$ and $28 \%$ to R8.

These results imply that the cost effectiveness of adding insulation to ducts already insulated to R4.2 will be much worse than for uninsulated or poorly insulated ducts. If we also include practical space considerations (R8 adds about six inches $(150 \mathrm{~mm}$ ) to the duct diameter) a couple of optimum options appear. For new installations that can be more flexible about duct size, R6 ducts represent an effective upper limit for duct insulation with little to be gained by going to R8. Similarly, if decisions are being made about adding insulation to ducts, if ducts already have R4.2 or greater insulation, then it is unlikely to be a practical and cost-effective measure to add insulation. Below this level however, ducts do receive considerable benefit from the added insulation. Lastly, in some cases the added insulation has very little benefit particularly when the ducts are in locations whose temperature differences between air in the ducts and their surroundings is negligible (e.g., basement ducts used for cooling in Minneapolis).

\section{Heating system efficiency sensitivity to duct insulation}

For heating, the extreme location is also the attic, however the differences between the duct locations are less for the heating systems than for cooling systems. Because the temperature differences between the air in the ducts and their surroundings are bigger for heating (particularly for basement systems), the heating results were more sensitive to the duct insulation than the cooling results. The differences are illustrated in Figures 20 and 21 for attics and basements, respectively (the crawlspace results fall between the attic and basement results). The figures show that the maximum benefit of duct insulation is gained when ducts are in more extreme locations where losses are the greatest, just like in the cooling cases above. For the attic systems the efficiencies were increased by an average of $17 \%$ compared to only $9 \%$ for basement systems by increasing R-value from R2 to R8. The greatest change of $22 \%$ was for the attic system in Minneapolis and the smallest change was 7\% for the basement system in Miami. In terms of fractional changes in energy use the Minneapolis attic cooling system would use 42\% less energy with R8 rather than R2 insulation. For the crawlspace systems, the average change from R2 to R8 was $9 \%$ because the crawlspaces are almost the same temperature as the uninsulated basements. These results indicate that retrofit programs or new home specifications for better duct insulation for heating ducts could be applied to a wider range of systems than for cooling because both the attic and crawlspace systems show significant savings potential. Note that for ducts inside a crawlspace or basement that is insulated, or in the limiting case of ducts in a basement that is conditioned space, the efficiencies are much higher and duct insulation becomes less important from an efficiency point of view because most of or all the conduction losses are to conditioned space. 


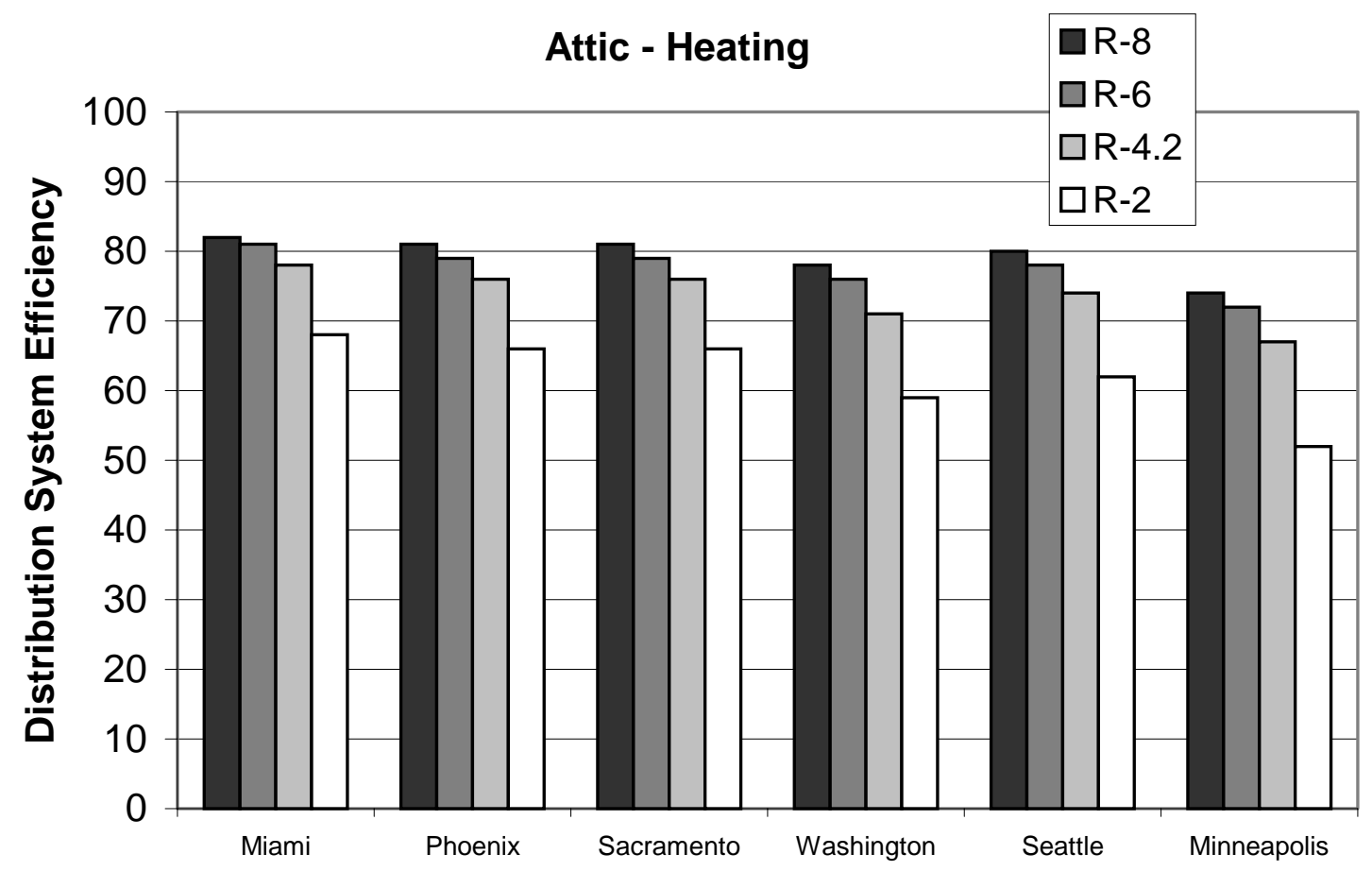

Figure 20. Climate and duct insulation effects for Heating Attic Ducts

Basement - Heating

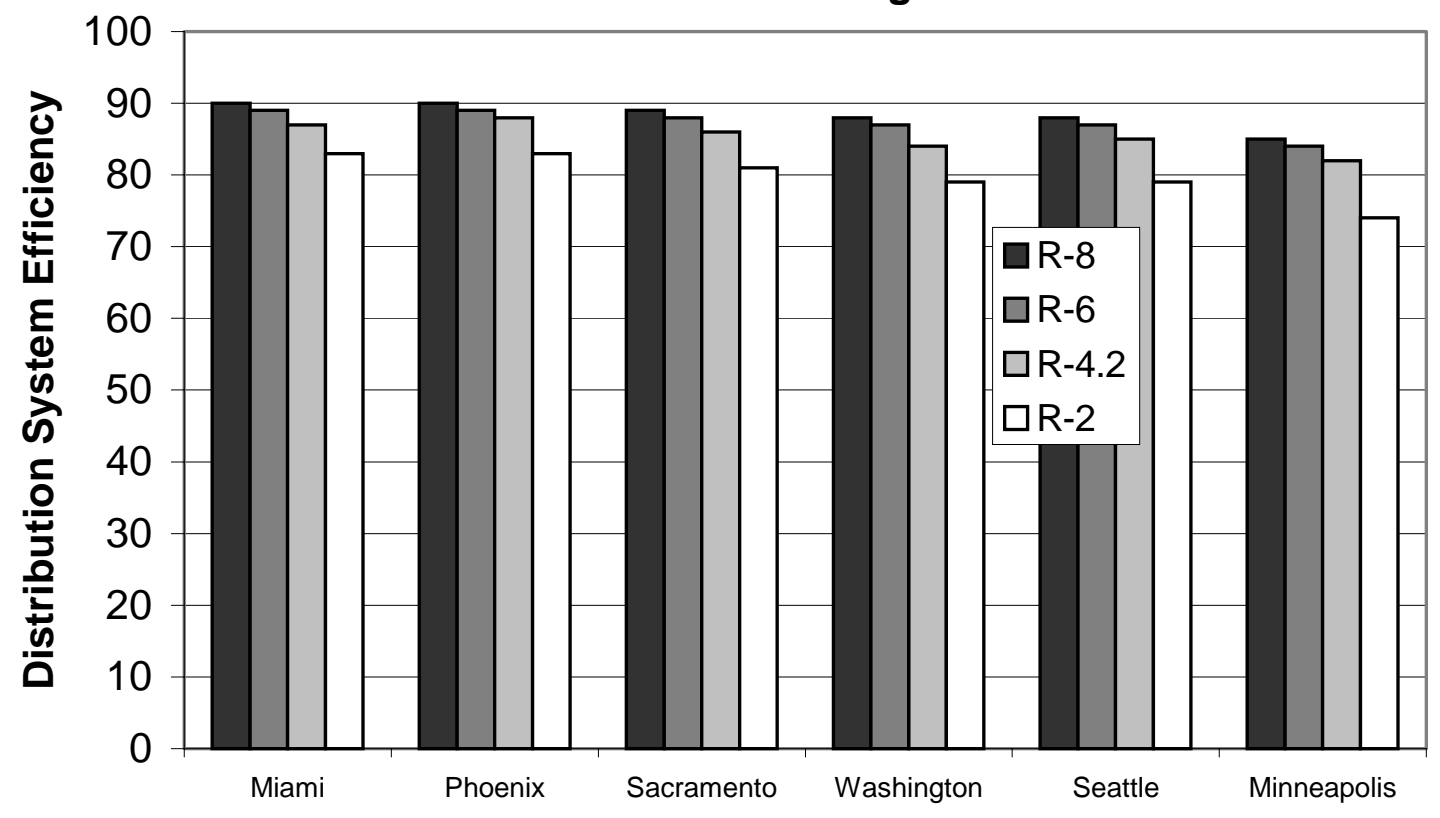

Figure 21. Climate and duct insulation effects for Heating Basement Ducts

The above results for changing duct insulation were all calculated for systems with $10 \%$ supply and $10 \%$ return leakage. Because the sensitivity to insulation addition depends on the fraction of losses that are by conduction, the calculations were repeated for systems with 5\% supply and 5\% return leakage. The results of these lower leakage calculations have the expected increases in duct efficiency due to reduced leakage for all cases (about 2 to 3\% for crawlspaces and basement and 7\% for attics), however, the changes in 
efficiency as insulation levels are increased show very little change, as shown in Figure 22. These results indicate that there are substantial savings to be gained by insulating less leaky ducts as well as less efficient leaky ducts. The changes in energy use are very close to the values for more leaky ducts because of the combination of slightly higher efficiency values and slightly greater efficiency changes.

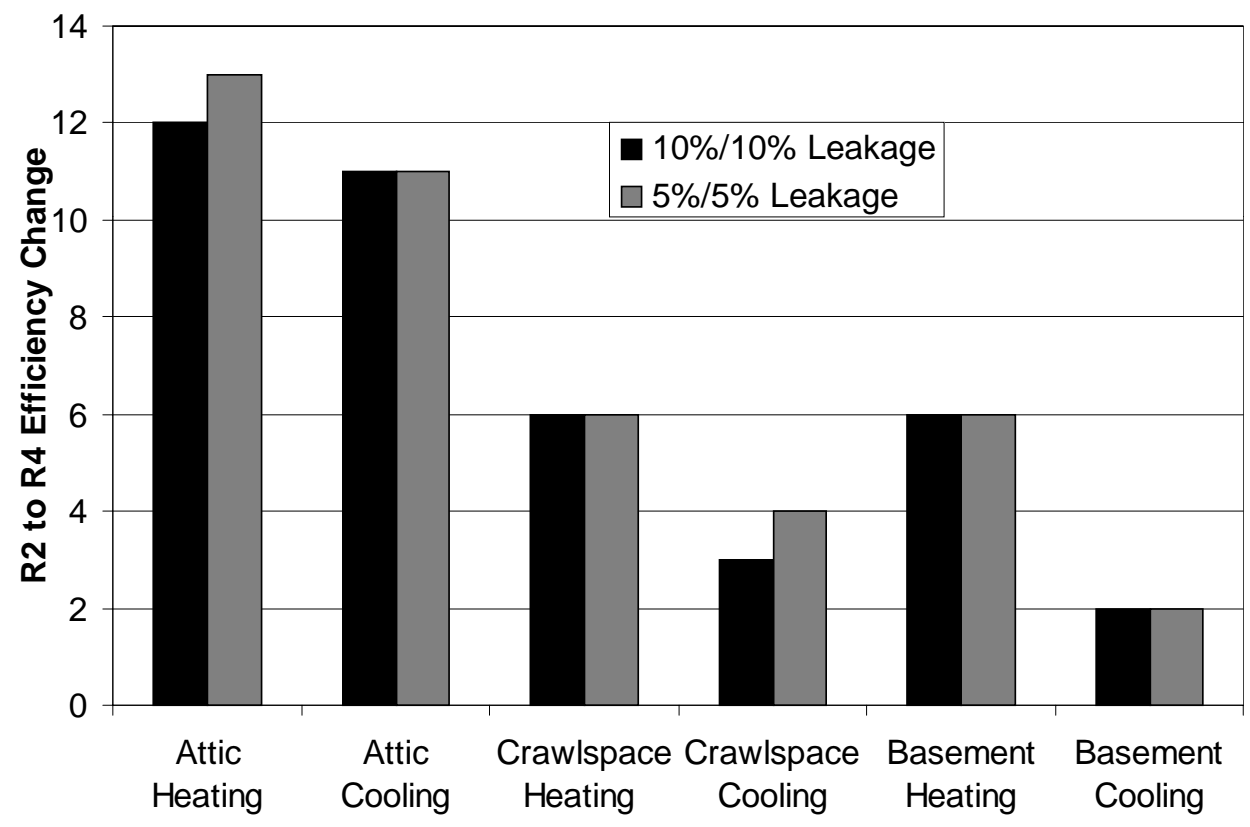

Figure 22. Comparison of distribution system efficiency changes by adding insulation to typical (10\% supply and $10 \%$ return leakage) and tight (5\% supply and $5 \%$ return leakage) systems

\section{Reduced Capacity Equipment}

Another set of calculations were performed in order to examine the effects of reducing both equipment capacity and air handler flow rate (but retaining the same fractional leakage). These calculations simulated the behavior of a multi-capacity system that is connected to an unchanging duct system. The objective was to examine the potential for duct efficiency reductions that compromise the efficiency improvements associated with multi-capacity systems. The typical system was used with $10 \%$ supply and $10 \%$ return leakage, R4 Attic duct insulation and R2 duct insulation in crawlspaces and basements. The results are summarized in Figures 23 and 24.

For the heating cases, the duct efficiency was reduced by about $10 \%$ (from $77 \%$ to $67 \%$ ) with the reduced capacity and flows. The biggest change was $14 \%$ for Minneapolis attic ducts, and the least change was $8 \%$ for Miami basement ducts. For the cooling cases, the effects were less significant. The duct efficiency was reduced by about $6 \%$ (from $80 \%$ to $74 \%$ ) with the reduced capacity and flows. The biggest change was $13 \%$ for Phoenix attic ducts, and there was no change for Minneapolis basement ducts. The reductions in efficiency are mainly due to the longer residence time in the ducts at reduced flow rates that leads to increased conduction losses. These results imply that the effect of using the same duct system with reduced capacity and air handler flow equipment is significant and needs to be included when estimating any overall system efficiency improvements from multi-capacity systems. Because of the large range of effect (from $14 \%$ to no change), the use of reduced capacity systems will be of more benefit in some climates and duct locations than others, specifically, the effects are reduced when the temperature difference for conduction losses is minimized. Therefore the multi-capacity equipment will generally perform worse for attic systems than for basement systems and will deliver the greatest benefit in milder climates. 


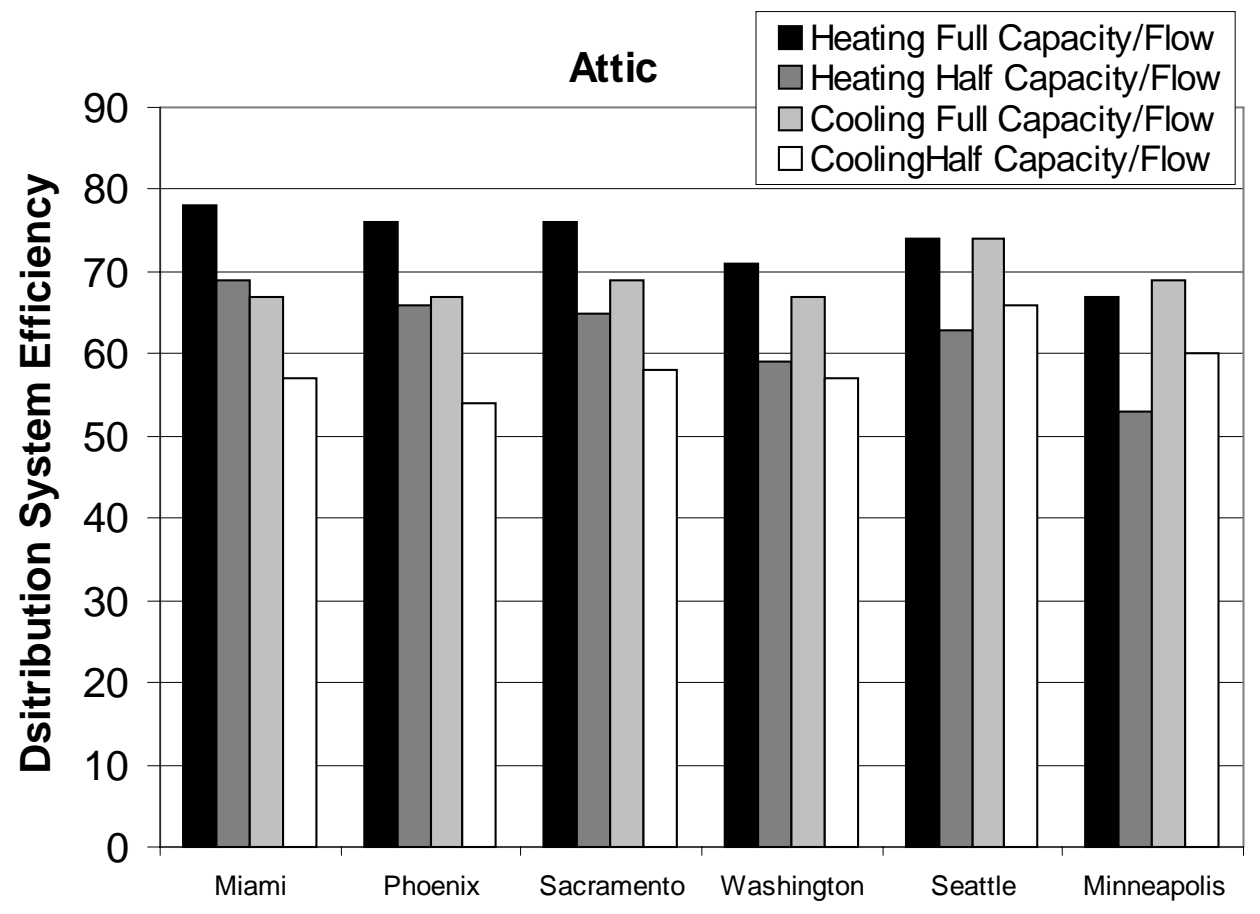

Figure 23. Changes in efficiency for multi-capacity attic systems

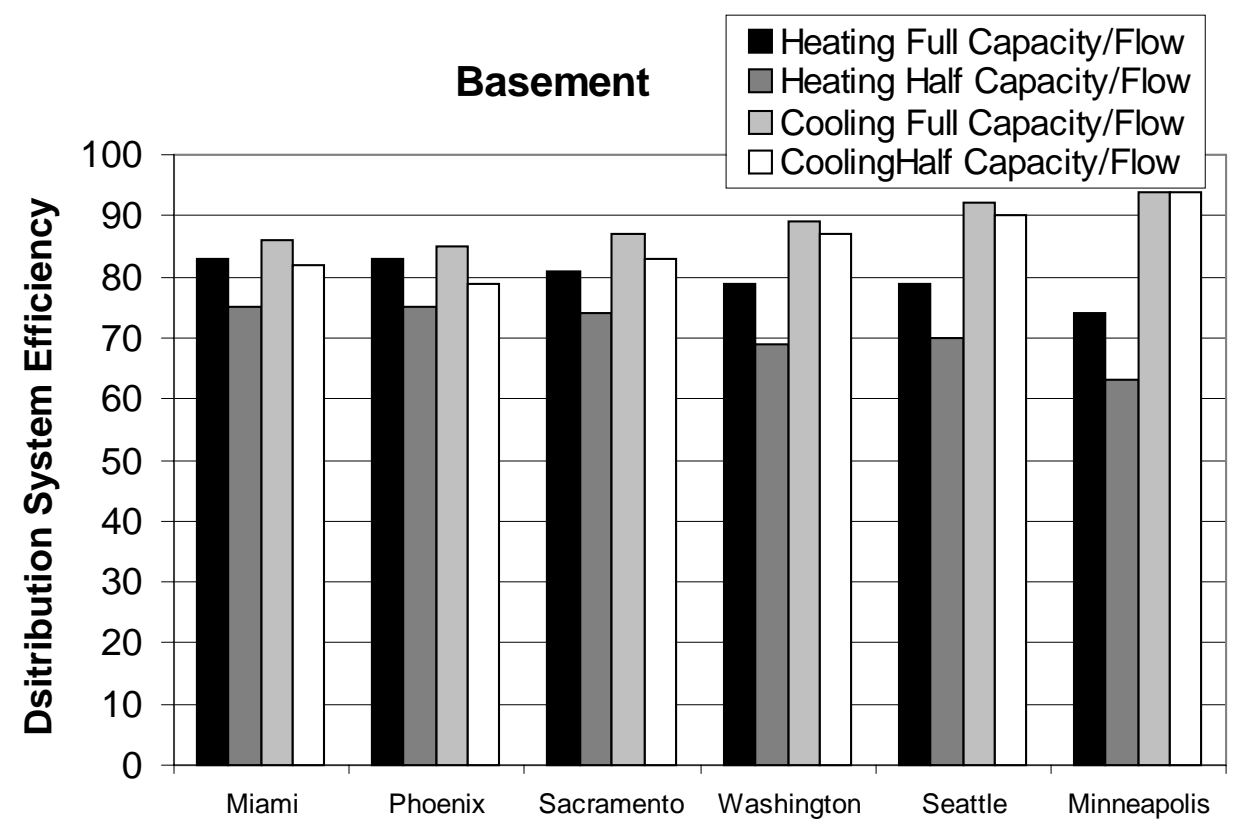

Figure 24. Changes in efficiency for multi-capacity basement systems

Design Condition Calculations for sensitivity to peak power availability and pricing

All of the previous results have been based on using seasonal weather conditions that were developed for energy use calculations. Recent increases in peak energy prices and interest in time of use pricing for residences mean that design condition efficiency also ratings need to be examined. The design condition calculations can be used to determine system capacity and the potential for peak energy/power savings. 
The design conditions are more extreme than the seasonal conditions (as shown in tables 1 and 2) and lead to lower distribution system efficiencies. Improvements in efficiency due to reduced leakage and increased insulation are therefore greater at design conditions. The results of the design calculations for a system with typical leakage show that the attic system efficiencies are considerably reduced compared to seasonal efficiencies, but the crawlspace and basement systems are only slightly affected. In the most extreme case, cooling ducts in an attic in Phoenix change design efficiency from $28 \%$ to $60 \%$ as insulation is increased from R2 to R8. Averaged over all the climates the cooling attic systems increase efficiency from $39 \%$ to $65 \%$ as insulation is increased from R2 to R8. These large increases indicate that for some cooling attic systems the energy use at design conditions could be halved by adding insulation. This would also have a particularly significant effect on the cost of cooling the homes if tome of use pricing were in effect. For basement and crawlspace systems the sensitivity to changes in duct insulation is about the same (within 1\% on average) as for the seasonal condition results presented earlier. Figure 25 illustrates the low efficiencies and sensitivity to duct insulation for an attic cooling systems. Figure 26 shows the same effects for attic heating systems. These figures clearly show the stronger influence of climate at design conditions compared to seasonal conditions (see Figures 18 and 20).

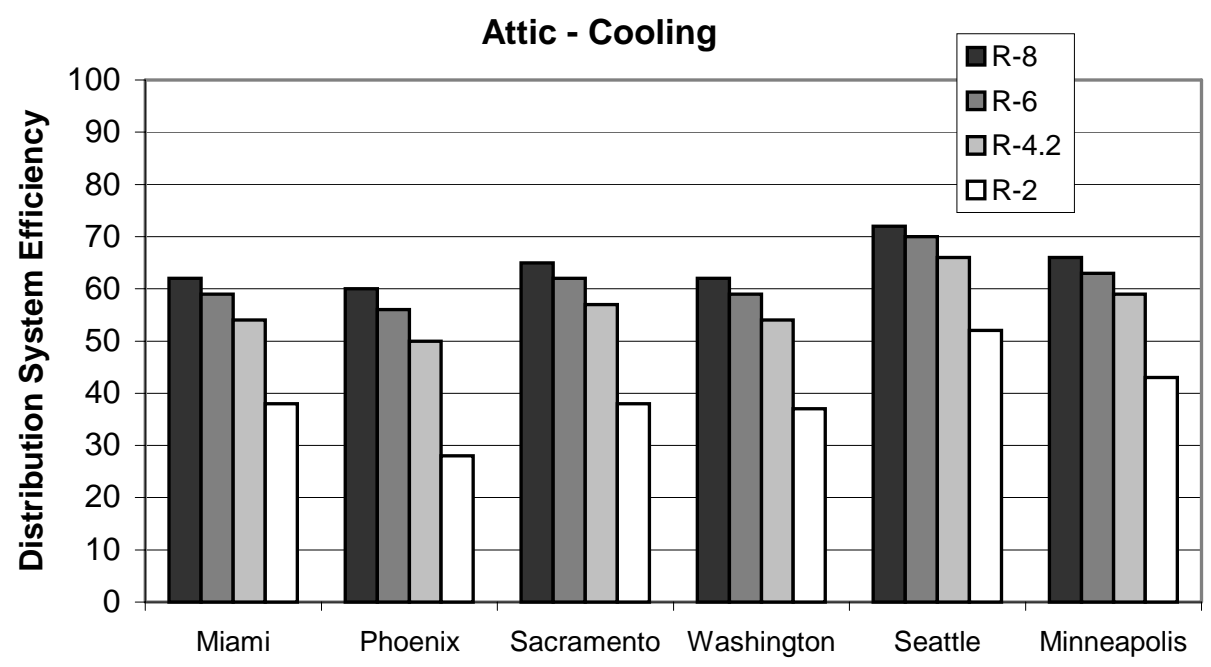

Figure 25. Climate and duct insulation effects on attic system efficiencies at design conditions

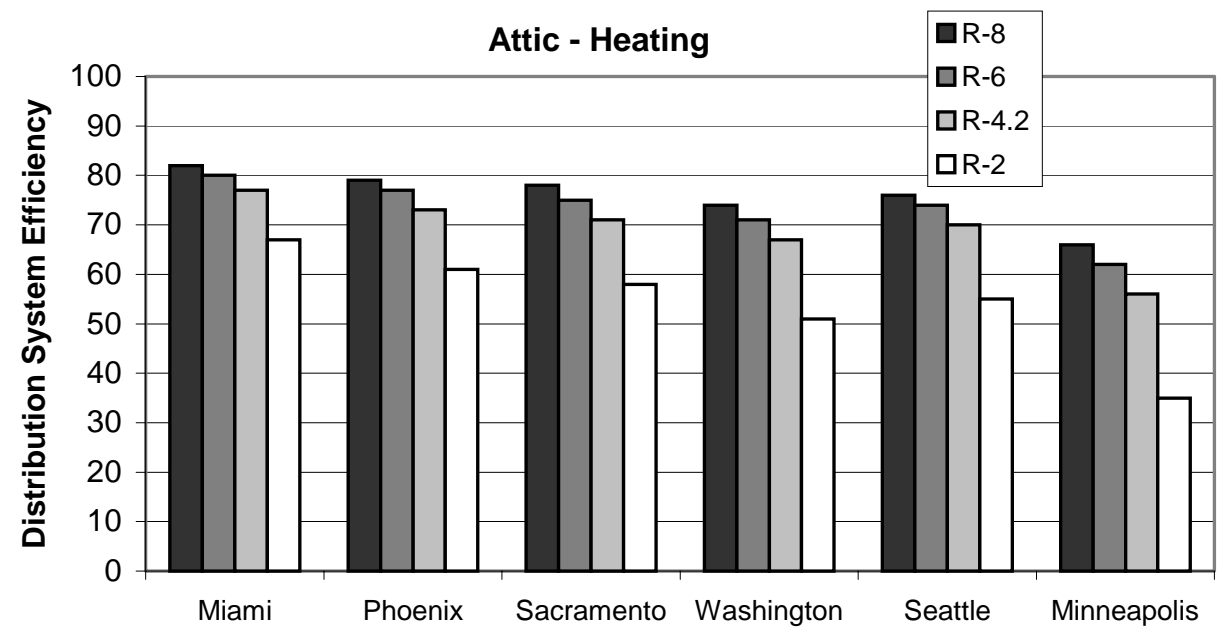

Figure 26. Climate and duct insulation effects on attic system efficiencies at design conditions 


\section{Summary}

The results of the 152P calculations show that the efficiency is strongly dependent on climate, duct location and leakage. This means that picking a single efficiency limit or leakage limit for national codes or standards creates problems. Choosing a single efficiency limit that is too high (e.g., 90\%) essentially prohibits some duct locations in some climates (attic ducts in Miami) and allows some systems (e.g., ducts in insulated basements) to have as much leakage as they want. Similarly, a single leakage specification results in acceptable duct systems in some climates, but not in others.

A reasonable alternative is to use two specifications:

1. No less than $80 \%$ efficiency according to $152 \mathrm{P}$, and no more than $20 \%$ total duct leakage (combined supply and return).

2. No more than $10 \%$ total leakage (combined supply and return) and at least R6 on ducts outside conditioned space. This combination of leakage and insulation gives efficiencies of almost $80 \%$ even in the extreme cases of Phoenix and Miami attic ducts for cooling.

The $80 \%$ efficiency limit eliminates duct systems in severe climates if they are of typical construction. The leakage limit prevents systems inside conditioned space from meeting the specification (i.e., you would not want to call a duct system with $15 \%$ leakage on each side a good system due to uneven distribution, bypass of filters etc.). However, it is possible to meet this $80 \%$ specification with improved duct systems (less than $10 \%$ total (supply plus return) leakage and R6 or R8 insulation), which is a result that one would like to have for an Energy Star program.

For cooling duct systems, for both adding insulation and reducing leakage, the maximum benefit is gained when ducts are in extreme locations. For example for an attic in the summer in Phoenix, the efficiencies can be increased by up to 20 percentage points (corresponding to a $35 \%$ reduction energy consumption). The average fractional change in energy consumption form adding insulation beyond the typical R4.2 standard found in many systems was about $4 \%$ for R6 and 7\% for R8. For less insulated ducts (starting at R2 - more typical of older systems) the reductions in energy consumption are greater, at about $19 \%$ for $\mathrm{R} 4.2$ and $28 \%$ for R8. These effects are highly variable - being greater for more extreme climates and duct locations, so it is necessary to take these variables into account when assessing the cost-effectiveness or simple benefits of duct insulation. In this study, the minimum insulation level was R2, but completely uninsulated ducts will have an effective thermal resistance approaching R1 and would see even greater benefits from added insulation.

As insulation is added in steps from R2 to R8 there are diminishing returns with each step. If we also include practical space considerations (R8 adds about six inches $(150 \mathrm{~mm}$ ) to the duct diameter) a couple of optimum options appear. For new installations that can be more flexible about duct size R6 ducts are good for most cases. Similarly, if decisions are being made about adding insulation to ducts, if ducts already have R4.2 or greater insulation, then it is unlikely to be a practical and cost-effective measure to add insulation. Below this level however, ducts do receive considerable benefit from the added insulation. Lastly, in some cases the added insulation has very little benefit particularly when the ducts are in locations whose temperature differences between air in the ducts and their surroundings is negligible (e.g., basement ducts used for cooling in Minneapolis).

For heating duct systems, a few results are more extreme than for cooling. However, the majority of the improvements due to reducing leakage and increasing insulation are similar to the cooling results, just with slightly lower magnitude. The same requirements for giving good results during cooling operation can therefore be applied to heating operation, except that the extreme climates change to be those that are heating dominated. For example, when selecting an appropriate insulation level for heating ducts, R4 or R6 is acceptable, R2 is too little insulation and there is little benefit to improve from R6 to R8.

The effects of duct leakage imbalance were investigated by comparing efficiencies of systems with 5\% supply/15\% return, and $15 \%$ supply $/ 5 \%$ return leakage to a balanced system with the same total leakage. The resulting imbalance flow rate is close to the natural ventilation rate expected for the house size used in this study. The main effect of the leakage imbalance is to change the house infiltration rate. The excess 
supply leakage (that increases house infiltration) resulted in about $6 \%$ lower efficiencies on average, while the excess return (with corresponding lower infiltration) leakage resulted in about $6 \%$ higher efficiencies. All the heating and cooling cases were within a couple of percentage points of this $6 \%$ average. Although the excess return leakage efficiency increases seem to indicate that added return leakage is a good idea, in some climates (e.g. humid and cooling) the increases are much smaller. In addition the entry of unfiltered air into the system from locations that could contain harmful pollutants is not recommended.

The effect of low air handler flow was investigated for cooling systems by reducing the air flow by $20 \%$. This lower air flow results in higher conduction losses, lower return leakage effects and reduced equipment efficiency. These effects combined to lower the efficiency by about $4 \%$ on average, with cooler climates and ducts duct locations about another $1 \%$ lower in efficiency.

Some HVAC equipment operates at multiple capacities in order to be more efficient at part-load conditions. However, the lower air flows and capacities can lead to reduced duct system efficiencies due to increased conduction losses that counteract these equipment performance gains. Using half flow and half capacity for a typical system showed $10 \%$ losses on average for heating systems and $6 \%$ average losses for cooling systems. There was significant climate and duct location variability. For example heating system ducts in an attic in Minneapolis have 14\% lower efficiency and cooling ducts in a Phoenix attic have 13\% less efficiency. When converting to changes in energy performance these represent about 20 to $25 \%$ reductions that could easily be greater than the equipment efficiency improvements. These results imply that the gains from multi-capacity systems can only be realized in some climates and with less extreme duct locations.

All of the above results are for seasonal conditions for energy use calculations. It is becoming increasingly important to examine the HVAC system performance at peak or design conditions in order to have improved sizing estimates and to estimate the potential effects of time of use pricing. The design climate conditions are more extreme than the seasonal climates and result in lower duct efficiencies. For crawlspaces and basements the efficiencies are typically a couple of percent lower than for the seasonal cases, but for attics the changes are much greater. For example, many locations have duct efficiencies less than $50 \%$ at design conditions, and a few are less than $30 \%$, for a typical system with $10 \%$ supply and $10 \%$ return leakage. Overall, the changes in efficiency from improving duct systems by adding insulation and reducing leakage are doubled at design conditions compared to seasonal conditions. This result indicates that duct improvements may become more cost effective under time of use policies where peak power costs more.

\section{References}

ACCA. 1997. ACCA Manual D - Residential Duct Systems. Washington, DC. Air Conditioning Contractors of America.

ASHRAE. 1999. Public Review Draft of ASHRAE Standard 152P "Method of Test for Determining the Design and Seasonal Efficiencies of Residential Thermal Distribution Systems" . ASHRAE. Atlanta. GA. For title, purpose and scope go to ttp://www.ashrae.org/STANDARDS/110-s161.htm

ASHRAE. 2001. Second Public Review Draft of ASHRAE Standard 152P "Method of Test for Determining the Design and Seasonal Efficiencies of Residential Thermal Distribution Systems". ASHRAE. Atlanta. GA.

CEC.1998. Low-rise Residential Alternative Calculation Method Approval Manual for 1998 Energy Efficiency Standards for Low-Rise Residential Buildings. California Energy Commission, Sacramento, California.

http://www.energy.ca.gov/title24/residential_acm/index.html

CEC. 1998. Title 24, Section 6. Energy Efficiency Standards for Residential and Nonresidential Buildings. California Energy Commission, Sacramento, California. http://www.energy.ca.gov/title24/98_standards/index.html 
Modera, M.P., and Wilcox, B. 1995. Treatment of residential duct leakage in Title 24 energy efficiency standards. California Energy Commission Contract Report

Walker, I.S., Sherman, M.H. and Siegel, J.A. 1999. Distribution Effectiveness and Impacts on Equipment Sizing for Residential Thermal Distribution Systems. LBNL 43724.

Walker, I.S., Sherman, M.H., Modera, M.P. and Siegel, J.A. 1997. Leakage Diagnostics, Sealant Longevity, Sizing and Technology Transfer in Residential Thermal Distribution Systems. LBNL 41118.

Walker, I.S. 1998. Technical Background for Default Values used for Forced Air Systems in Proposed ASHRAE Standard 152P. ASHRAE Trans., Vol. 104, part 1 .LBNL 40588. 


\section{Appendix. Results of duct efficiency calculations}

\begin{tabular}{|c|c|c|c|c|c|c|c|c|c|}
\hline & \multirow[b]{2}{*}{ Insulation } & \multicolumn{4}{|c|}{$\begin{array}{c}\text { Duct Efficiency for } \\
\text { HEATING }\end{array}$} & \multicolumn{4}{|c|}{ Duct Efficiency for COOLING } \\
\hline & & R-8 & R-6 & $\mathrm{R}-4.2$ & R-2 & $\mathbf{R - 8}$ & R-6 & R-4.2 & R-2 \\
\hline Duct Location & Climate & & & & & & & & \\
\hline \multirow[t]{6}{*}{ Attic } & Miami & 82 & 81 & 78 & 68 & 71 & 70 & 67 & 56 \\
\hline & Phoenix & 81 & 79 & 76 & 66 & 73 & 71 & 67 & 54 \\
\hline & Sacramento & 81 & 79 & 76 & 66 & 75 & 72 & 69 & 58 \\
\hline & Washington & 78 & 76 & 71 & 59 & 73 & 71 & 67 & 57 \\
\hline & Seattle & 80 & 78 & 74 & 62 & 79 & 77 & 74 & 65 \\
\hline & Minneapolis & 74 & 72 & 67 & 52 & 74 & 72 & 96 & 59 \\
\hline \multirow{6}{*}{$\begin{array}{c}\text { Vented } \\
\text { Crawlspace }\end{array}$} & Miami & 88 & 88 & 86 & 81 & 88 & 86 & 85 & 82 \\
\hline & Phoenix & 88 & 87 & 85 & 80 & 88 & 88 & 87 & 83 \\
\hline & Sacramento & 88 & 87 & 85 & 80 & 89 & 88 & 87 & 84 \\
\hline & Washington & 87 & 86 & 84 & 77 & 88 & 87 & 86 & 83 \\
\hline & Seattle & 88 & 87 & 84 & 79 & 91 & 90 & 89 & 87 \\
\hline & Minneapolis & 85 & 84 & 82 & 75 & 89 & 88 & 87 & 84 \\
\hline \multirow[t]{6}{*}{ Basement } & Miami & 90 & 89 & 87 & 83 & 90 & 89 & 88 & 86 \\
\hline & Phoenix & 90 & 89 & 88 & 83 & 89 & 89 & 88 & 85 \\
\hline & Sacramento & 89 & 88 & 86 & 81 & 91 & 91 & 90 & 87 \\
\hline & Washington & 88 & 87 & 84 & 79 & 92 & 91 & 91 & 89 \\
\hline & Seattle & 88 & 87 & 85 & 79 & 94 & 94 & 93 & 92 \\
\hline & Minneapolis & 85 & 84 & 82 & 74 & 95 & 95 & 94 & 94 \\
\hline
\end{tabular}




\begin{tabular}{|c|c|c|c|c|c|c|c|c|c|}
\hline & \multirow[b]{2}{*}{ Insulation } & \multicolumn{4}{|c|}{$\begin{array}{l}\text { Duct Efficiency for } \\
\text { HEATING }\end{array}$} & \multicolumn{4}{|c|}{ Duct Efficiency for COOLING } \\
\hline & & $\mathbf{R - 8}$ & R-6 & R-4.2 & R-2 & $\mathbf{R - 8}$ & R-6 & R-4.2 & R-2 \\
\hline Duct Location & Climate & & & & & & & & \\
\hline \multirow[t]{6}{*}{ Attic } & Miami & 87 & 85 & 82 & 72 & 81 & 79 & 76 & 65 \\
\hline & Phoenix & 86 & 84 & 81 & 70 & 81 & 79 & 75 & 61 \\
\hline & Sacramento & 86 & 84 & 80 & 68 & 82 & 80 & 76 & 64 \\
\hline & Washington & 84 & 81 & 76 & 63 & 82 & 80 & 76 & 66 \\
\hline & Seattle & 85 & 83 & 78 & 66 & 85 & 84 & 80 & 71 \\
\hline & Minneapolis & 81 & 78 & 73 & 56 & 83 & 81 & 78 & 66 \\
\hline \multirow{6}{*}{$\begin{array}{c}\text { Vented } \\
\text { Crawlspace }\end{array}$} & Miami & 92 & 91 & 89 & 83 & 91 & 91 & 90 & 86 \\
\hline & Phoenix & 91 & 90 & 88 & 83 & 92 & 91 & 90 & 86 \\
\hline & Sacramento & 91 & 90 & 88 & 82 & 92 & 92 & 90 & 87 \\
\hline & Washington & 90 & 89 & 87 & 80 & 92 & 91 & 90 & 87 \\
\hline & Seattle & 91 & 90 & 87 & 81 & 94 & 93 & 92 & 89 \\
\hline & Minneapolis & 89 & 88 & 86 & 78 & 92 & 92 & 91 & 87 \\
\hline \multirow[t]{6}{*}{ Basement } & Miami & 92 & 91 & 90 & 85 & 93 & 93 & 92 & 89 \\
\hline & Phoenix & 92 & 91 & 90 & 85 & 93 & 92 & 91 & 87 \\
\hline & Sacramento & 92 & 91 & 89 & 83 & 94 & 93 & 92 & 90 \\
\hline & Washington & 91 & 90 & 87 & 81 & 94 & 94 & 93 & 92 \\
\hline & Seattle & 91 & 90 & 88 & 82 & 96 & 95 & 95 & 94 \\
\hline & Minneapolis & 89 & 88 & 85 & 78 & 96 & 96 & 96 & 96 \\
\hline
\end{tabular}


Table A3. Dependence of ASHRAE 152P Duct Efficiency on duct leakage

\begin{tabular}{|c|c|c|c|c|c|c|c|}
\hline & \multirow[b]{2}{*}{ Leakage } & \multicolumn{3}{|c|}{ Duct Efficiency for HEATING } & \multicolumn{3}{|c|}{ Duct Efficiency for COOLING } \\
\hline & & $\begin{array}{l}14 \% \mathrm{~S}, \\
14 \% \mathrm{R}\end{array}$ & $\begin{array}{l}10 \% \mathrm{~S}, \\
10 \% \mathrm{R}\end{array}$ & $\begin{array}{l}5 \% \mathrm{~S}, \\
5 \% \mathrm{R}\end{array}$ & $\begin{array}{l}14 \% \mathrm{~S}, \\
14 \% \mathrm{R}\end{array}$ & $\begin{array}{l}10 \% \mathrm{~S}, \\
10 \% \mathrm{R}\end{array}$ & $\begin{array}{l}5 \% \mathrm{~S}, \\
5 \% \mathrm{R}\end{array}$ \\
\hline Duct Location & Climate & & & & & & \\
\hline \multirow{6}{*}{$\begin{array}{l}\text { Attic } \\
\text { R4.2 }\end{array}$} & Miami & 74 & 78 & 82 & 59 & 67 & 76 \\
\hline & Phoenix & 72 & 76 & 81 & 61 & 67 & 75 \\
\hline & Sacramento & 72 & 76 & 80 & 63 & 69 & 78 \\
\hline & Washington & 67 & 71 & 76 & 61 & 67 & 76 \\
\hline & Seattle & 70 & 74 & 79 & 70 & 74 & 81 \\
\hline & Minneapolis & 62 & 67 & 73 & 63 & 69 & 78 \\
\hline \multirow{6}{*}{$\begin{array}{l}\text { Attic with RB } \\
\mathrm{R} 4.2 *\end{array}$} & Miami & - & - & - & 63 & 70 & 79 \\
\hline & Phoenix & - & - & - & 67 & 72 & 78 \\
\hline & Sacramento & - & - & - & 68 & 73 & 80 \\
\hline & Washington & - & - & - & 64 & 71 & 79 \\
\hline & Seattle & - & - & - & 72 & 77 & 83 \\
\hline & Minneapolis & - & - & - & 67 & 73 & 80 \\
\hline \multirow{6}{*}{$\begin{array}{l}\text { Uninsulated } \\
\text { Vented } \\
\text { Crawlspace } \\
\text { R2.1 }\end{array}$} & Miami & 79 & 81 & 83 & 79 & 82 & 86 \\
\hline & Phoenix & 78 & 80 & 83 & 80 & 83 & 86 \\
\hline & Sacramento & 78 & 80 & 83 & 82 & 84 & 87 \\
\hline & Washington & 75 & 77 & 80 & 80 & 83 & 87 \\
\hline & Seattle & 77 & 79 & 81 & 85 & 87 & 89 \\
\hline & Minneapolis & 73 & 76 & 79 & 81 & 84 & 87 \\
\hline \multirow{6}{*}{$\begin{array}{l}\text { Uninsulated } \\
\text { Basement } \\
\text { R1 }\end{array}$} & Miami & 74 & 75 & 76 & 80 & 82 & 85 \\
\hline & Phoenix & 74 & 75 & 76 & 77 & 79 & 82 \\
\hline & Sacramento & 72 & 73 & 75 & 82 & 83 & 86 \\
\hline & Washington & 68 & 69 & 71 & 85 & 87 & 89 \\
\hline & Seattle & 68 & 70 & 72 & 89 & 90 & 92 \\
\hline & Minneapolis & 62 & 63 & 66 & 93 & 94 & 96 \\
\hline
\end{tabular}

* - Radiant Barriers only effect cooling calculations 
Table A4. Dependence of ASHRAE 152P Duct Efficiency on imbalanced duct leakage

\begin{tabular}{|c|c|c|c|c|c|}
\hline & \multirow[b]{2}{*}{ Leakage } & \multicolumn{2}{|c|}{ Duct Efficiency for HEATING } & \multicolumn{2}{|c|}{ Duct Efficiency for COOLING } \\
\hline & & $5 \% \mathrm{~S}, 15 \% \mathrm{R}$ & $15 \% \mathrm{~S}, 5 \% \mathrm{R}$ & $5 \% \mathrm{~S}, 15 \% \mathrm{R}$ & $15 \% \mathrm{~S}, 5 \% \mathrm{R}$ \\
\hline Duct Location & Climate & & & & \\
\hline \multirow{2}{*}{$\begin{array}{l}\text { Attic } \\
\text { R4.2 }\end{array}$} & Miami & 84 & 73 & 70 & 63 \\
\hline & Minneapolis & 76 & 61 & 73 & 66 \\
\hline \multirow{2}{*}{$\begin{array}{c}\text { Attic with RB } \\
\text { R4.2 } \\
\end{array}$} & Miami & 84 & 84 & 74 & 65 \\
\hline & Minneapolis & 76 & 77 & 77 & 68 \\
\hline \multirow{2}{*}{$\begin{array}{c}\text { Vented } \\
\text { Crawlspace } \\
\text { R2.1 } \\
\end{array}$} & Miami & 86 & 78 & 90 & 75 \\
\hline & Minneapolis & 86 & 69 & 90 & 78 \\
\hline & & & & & \\
\hline \multirow{2}{*}{$\begin{array}{l}\text { Uninsulated } \\
\text { Basement } \\
\text { R1 }\end{array}$} & Miami & 80 & 71 & 91 & 73 \\
\hline & Minneapolis & 78 & 54 & 102 & 86 \\
\hline
\end{tabular}




\begin{tabular}{|c|c|c|}
\hline \multicolumn{3}{|c|}{$\begin{array}{l}\text { Table A5. Dependence of ASHRAE 152P Duct Efficiency on } \\
\text { reduced fan flows }(320 \mathrm{cfm} / \text { ton })\end{array}$} \\
\hline & & Duct Efficiency for COOLING \\
\hline & Leakage & $10 \% \mathrm{~S}, 10 \% \mathrm{R}$ \\
\hline Duct Location & Climate & \\
\hline \multirow{6}{*}{$\begin{array}{l}\text { Attic } \\
\text { R4.2 }\end{array}$} & Miami & 64 \\
\hline & Phoenix & 64 \\
\hline & Sacramento & 66 \\
\hline & Washington & 65 \\
\hline & Seattle & 74 \\
\hline & Minneapolis & 66 \\
\hline \multirow{6}{*}{$\begin{array}{l}\text { Attic with RB } \\
\quad \text { R4.2 }\end{array}$} & Miami & 67 \\
\hline & Phoenix & 68 \\
\hline & Sacramento & 69 \\
\hline & Washington & 67 \\
\hline & Seattle & 77 \\
\hline & Minneapolis & 69 \\
\hline \multirow{6}{*}{$\begin{array}{l}\text { Uninsulated } \\
\text { Vented } \\
\text { Crawlspace } \\
\text { R2.1 }\end{array}$} & Miami & 77 \\
\hline & Phoenix & 78 \\
\hline & Sacramento & 79 \\
\hline & Washington & 78 \\
\hline & Seattle & 81 \\
\hline & Minneapolis & 79 \\
\hline \multirow{6}{*}{$\begin{array}{l}\text { Uninsulated } \\
\text { Basement } \\
\text { R1 }\end{array}$} & Miami & 77 \\
\hline & Phoenix & 74 \\
\hline & Sacramento & 78 \\
\hline & Washington & 81 \\
\hline & Seattle & 84 \\
\hline & Minneapolis & 87 \\
\hline
\end{tabular}




\begin{tabular}{|c|c|c|c|}
\hline \multicolumn{4}{|c|}{$\begin{array}{l}\text { Table A6. Dependence of ASHRAE } 152 P \text { Duct Efficiency with half } \\
\text { flow and half capacity and } 10 \% \text { supply and } 10 \% \text { return leakage }\end{array}$} \\
\hline Duct Location & Climate & $\begin{array}{l}\text { Duct Efficiency } \\
\text { for HEATING }\end{array}$ & $\begin{array}{c}\text { Duct } \\
\text { Efficiency for } \\
\text { COOLING }\end{array}$ \\
\hline \multirow{6}{*}{$\begin{array}{l}\text { Attic } \\
\text { R4.2 }\end{array}$} & Miami & 69 & 57 \\
\hline & Phoenix & 66 & 54 \\
\hline & Sacramento & 65 & 58 \\
\hline & Washington & 59 & 57 \\
\hline & Seattle & 63 & 66 \\
\hline & Minneapolis & 53 & 60 \\
\hline \multirow{6}{*}{$\begin{array}{c}\text { Vented } \\
\text { Crawlspace } \\
\text { R2 }\end{array}$} & Miami & 72 & 77 \\
\hline & Phoenix & 71 & 6 \\
\hline & Sacramento & 70 & 77 \\
\hline & Washington & 67 & 77 \\
\hline & Seattle & 69 & 82 \\
\hline & Minneapolis & 65 & 79 \\
\hline \multirow{6}{*}{$\begin{array}{l}\text { Basement } \\
\text { R2 }\end{array}$} & Miami & 75 & 52 \\
\hline & Phoenix & 75 & 79 \\
\hline & Sacramento & 73 & 83 \\
\hline & Washington & 69 & 87 \\
\hline & Seattle & 70 & 90 \\
\hline & Minneapolis & 63 & 94 \\
\hline
\end{tabular}




\begin{tabular}{|c|c|c|c|c|c|c|c|c|c|}
\hline & & \multicolumn{4}{|c|}{$\begin{array}{c}\text { Duct Efficiency for } \\
\text { HEATING }\end{array}$} & \multicolumn{4}{|c|}{ Duct Efficiency for COOLING } \\
\hline & Insulation & R-8 & R-6 & R-4.2 & R-2 & R-8 & R-6 & R-4.2 & R-2 \\
\hline Duct Location & Climate & & & & & & & & \\
\hline \multirow[t]{6}{*}{ Attic } & Miami & 82 & 80 & 77 & 67 & 62 & 59 & 54 & 38 \\
\hline & Phoenix & 79 & 77 & 73 & 61 & 60 & 56 & 50 & 28 \\
\hline & Sacramento & 78 & 75 & 71 & 58 & 65 & 62 & 57 & 38 \\
\hline & Washington & 74 & 71 & 67 & 51 & 62 & 59 & 54 & 37 \\
\hline & Seattle & 76 & 74 & 70 & 55 & 72 & 70 & 66 & 52 \\
\hline & Minneapolis & 66 & 62 & 56 & 35 & 66 & 63 & 59 & 43 \\
\hline \multirow{6}{*}{$\begin{array}{c}\text { Vented } \\
\text { Crawlspace }\end{array}$} & Miami & 88 & 87 & 86 & 80 & 84 & 84 & 83 & 79 \\
\hline & Phoenix & 87 & 56 & 84 & 78 & 84 & 83 & 82 & 76 \\
\hline & Sacramento & 86 & 85 & 83 & 77 & 87 & 86 & 85 & 80 \\
\hline & Washington & 85 & 84 & 81 & 74 & 85 & 84 & 83 & 79 \\
\hline & Seattle & 86 & 85 & 83 & 76 & 90 & 89 & 88 & 85 \\
\hline & Minneapolis & 81 & 80 & 77 & 68 & 87 & 86 & 85 & 81 \\
\hline \multirow[t]{6}{*}{ Basement } & Miami & 90 & 89 & 87 & 82 & 87 & 87 & 86 & 83 \\
\hline & Phoenix & 89 & 89 & 87 & 82 & 90 & 89 & 89 & 85 \\
\hline & Sacramento & 88 & 87 & 86 & 80 & 89 & 88 & 87 & 84 \\
\hline & Washington & 87 & 86 & 84 & 77 & 89 & 89 & 88 & 86 \\
\hline & Seattle & 87 & 86 & 84 & 78 & 93 & 93 & 92 & 91 \\
\hline & Minneapolis & 83 & 82 & 79 & 72 & 93 & 93 & 93 & 92 \\
\hline
\end{tabular}

